\title{
LUGARES, FLUXOS E ITINERÁRIOS NO COMERCIO SEXUAL DE E NA RUA: REDES SOCIAIS NA CIDADE DE FLORIANÓPOLIS (SC)
}

\author{
Juliana Cavilha ${ }^{1}$
}

\section{Introdução}

\author{
Então como a gente é a primeira na praça, é nova \\ eles pagavam. Até hoje a mulher que não é rodada \\ vale mais. \\ Daí o cara me chamou pra fazer programa, me \\ pagou, eu peguei e fui! \\ (Denise, junho de 2007)
}

Entendo a prostituição como um trabalho e especialmente a prostituição de rua como uma categoria de trabalho que usa, para o exercício da sua atividade, o espaço das ruas nas grandes cidades, assim como os catadores de papel, os engraxates, os ambulantes e os mendigos entre outros. Todas essas categorias, no exercício de sua atividade, invariavelmente, ocupam as ruas, as esquinas, as praças, as saídas de metrô, de ônibus, dos trens, das portas de igrejas, dos restaurantes, enfim, circulam pela cidade ofertando os seus serviços e/ou produtos. São atividades que nas grandes metrópoles ganham o caráter de profissão (Park, 1976).

Assim, no exercício do trabalho da prestação de serviços sexuais em espaços públicos, fechados ou abertos, ao longo da carreira nas ruas da cidade, as "profissionais" precisam astuciosamente construir sua clientela entre os freqüentadores de tais locais. Isso lhes exige a aprendizagem de algumas táticas de ocupação territorial, as quais envolvem a competição com outras categorias de trabalhadores que atuam no setor, ou até mesmo, de outros setores, mas que obtêm seu sustento nos espaços públicos.

Como muitas das ocupações encontradas nas ruas da cidade, as prostitutas formam um grupo que atua num ramo de serviços considerados 'não convencionais', visto que o produto de seu trabalho está constantemente sujeito a sanções sociais de toda ordem. Estas sanções têm por objetivo dirigir a oferta e a procura dos produtos ou serviços oferecidos pelas prostitutas. Mesmo considerando-se seus intermediários

\footnotetext{
${ }^{1}$ Universidade Federal de Santa Catarina e Universidade Federal do Rio Grande do Sul, Brasil.
} 
(entenda-se aqui os cafetões, donos de boates, gerentes, etc.), e a extrema diferenciação dos produtos oferecidos pelo comércio sexual, pode-se afirmar que o que esta forma de trabalho tem em comum com as outras 'não-convencionais' é o fato de elas serem muito mais casual que outras profissões urbanas, que usufruem o status do trabalho regular e formal.

E assim, para que esta atividade se configure como uma ocupação do setor de serviços, ela depende de uma organização interna dos trabalhadores (homens e mulheres), suficientemente forte, para que o contato direto e pessoal deles com seus clientes e o serviço prestado, se transforme em laços de trabalho estáveis e duráveis ${ }^{2}$. Sem contar que o sucesso na carreira, nesse gênero de trabalho, depende de determinados arranjos ancorados nestas redes sociais formadas por colegas do métier, em que as mais antigas na "batalha" destacam-se por iniciar a neófita no curso da experiência imediata com a profissão.

Observei, durante o trabalho de campo ${ }^{4}$, que a profissional mais experiente, por exemplo, é aquela que detém o conhecimento dos "segredos" da profissão, das facilidades do "ponto", obtendo os melhores preços para os seus programas e usufruindo de uma clientela mais estável. É ali, na rua, o lugar/palco dessas negociações, dependendo de certa desenvoltura no exercício da atividade e, portanto, “de uma técnica consciente e específica de levá-la a termo" (Park, 1976, 41).

É por isso que o estudo das redes sociais (Lomnitz, 2001; Both,1976; FooteWhyte, 2005), para a compreensão da experiência do comércio sexual em Florianópolis, tornou-se um pertinente aliado na tese. Pois, é através do estudo de redes sociais é possível compreender o sexo mercantil conformado num complexo sistema de práticas e segundo diferentes visões de mundo. No interior das redes sociais e das cadeias relacionais que constituem o comércio sexual, a prática da prostituição abarca dilemas morais na forma como as diversas profissionais negociam com os imperativos morais herdados pela sociedade patriarcal. Afinal, a prostituição como categoria de trabalho contempla uma diversidade de estruturas sociais que envolvem o recrutamento de profissionais e de clientes, com base nas relações de vizinhança, de parentesco e de amizade.

\footnotetext{
2 Sobre as relações entre donos de boates e as profissionais do sexo e manutenção de clientela, ver: Simões, 2010.

${ }^{3}$ Termo usado em campo que significa prostituir-se nas ruas equivaleria a uma guerra.

${ }^{4} \mathrm{O}$ trabalho de campo para a pesquisa de doutorado aconteceu entre os anos de 2007 a 2008, com um retorno pontual em 2009 .
} 
Internamente, as redes sociais se organizam de modo informal, levando em consideração desde as negociações do lugar para a atividade, as hierarquias, a ordenação dos papéis, a manutenção dos lugares sociais, a mobilidade, a estrutura social, os diversos estilos de uma mesma atividade, e chegando à composição das parcerias sociais que se formam (e se dissolvem) ao longo da sua atuação na cidade.

Duas das três redes aqui dispostas pertencem às ruas da cidade, representadas por Denise e Nadia, as quais detêm, no fluxo da rede, uma posição de centralidade. A outra é a rede social formada em torno da organização ${ }^{5}$ não-governamental GAPA ${ }^{6}$ (Grupo de Apoio e Prevenção a AIDS), espaço em que Márcia, na ocasião de meu trabalho de campo, detinha um importante papel no fluxo comunicativo.

As redes sociais que explicitarei a seguir foram construídas a partir dos procedimentos de trabalho de campo e com base na realização da etnografia de rua (Eckert \& Rocha, 2003), sendo descritas com base em determinadas orientações culturais que seus membros integrantes constroem com suas unidades territoriais de trabalho.

\footnotetext{
${ }^{5}$ No centro da cidade de Florianópolis outras duas instituições atuam em projetos com as profissionais do sexo: a ONG Estrela Guia e o Instituto Arco-Íris. A primeira foi importante nesta pesquisa para o acesso inicial, pois, com esta ONG, realizei algumas saídas de campo para entrega de preservativos com voluntários e também auxiliei em pesquisa e mapeamento. Esta ONG é formada por ex-profissionais do sexo e ocupa a sede da ONG ADEH (organizada pelas travestis). Situam-se no centro da cidade, numa das salas do "antigo Hotel Royal" próximo a praça XV de Novembro. A Estrela Guia desenvolve projetos ligados à prevenção da DST/HIV Aids e a cidadania das profissionais do sexo. Possuem financiamentos do Ministério da Saúde e da Secretaria da Saúde do Estado de Santa Catarina. Com a ONG Arco Íris meu contato nesta pesquisa de doutorado não aconteceu, diferente da pesquisa realizada com a BEMFAM (nos anos de 2002 e de 2003) quando o contato era estreito.

${ }^{6}$ A ONG GAPA é localizada no alto de Rua Felipe Schmidt no centro de Florianópolis. Esta na capital há 26 anos.
} 


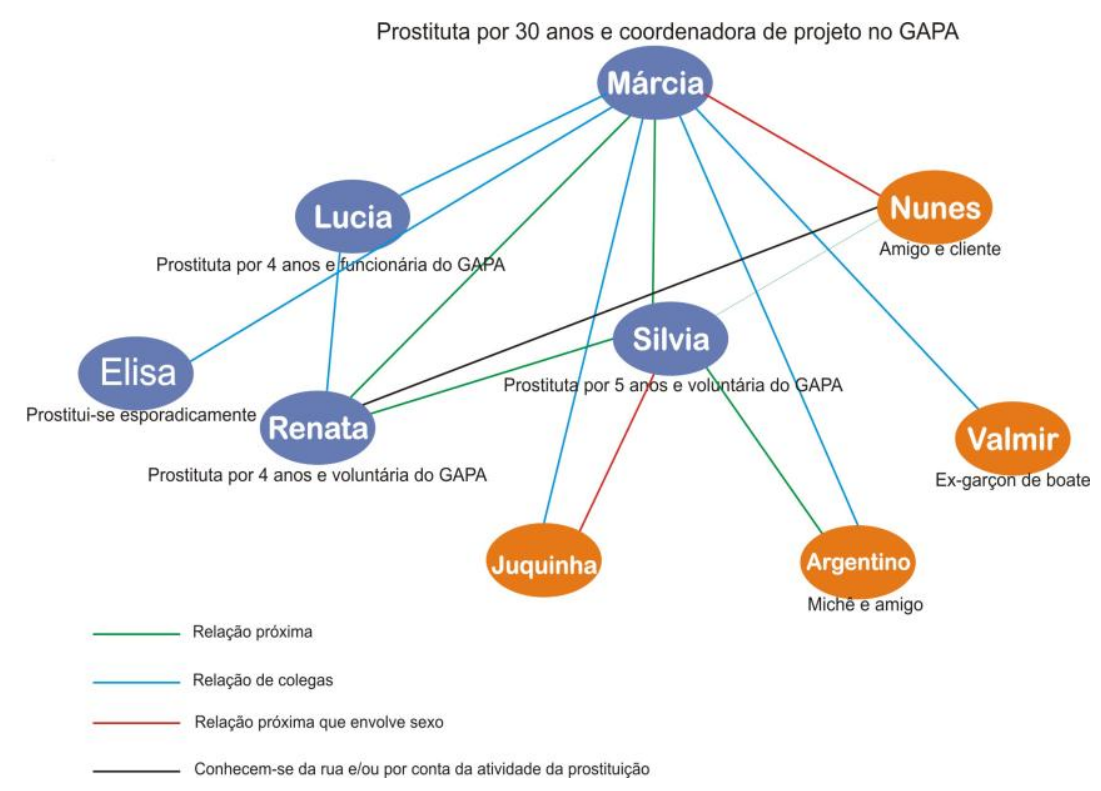

A primeira rede tem como âncora Márcia ${ }^{7}, 54$ anos, que centralizava na ocasião da pesquisa, através de sua atuação na ONG GAPA, um grande repertório de informações sobre o comércio sexual em Florianópolis, mantendo laços estreitos com colegas de profissão.

Márcia tem o Ensino Fundamental incompleto, é branca, católica, mas atualmente frequienta a seicho-no-ie. Nasceu em Biguaçu/SC, mas cresceu na cidade de Lages/SC. Como Márcia possui uma importante posição no GAPA, a densidade de sua rede está referida ao "controle social” por meio de ações preventivas de DST's, promovidas por esta instituição, sobre as práticas de comércio sexual na cidade.

Márcia trabalhava voluntariamente ${ }^{8}$ no GAPA, de segunda à sexta-feira, das 10 às 19h, concentrando responsabilidades diversas, tais como, distribuir preservativos, controlando sua doação entre os seus usuários, atendimento ao telefone, recepção, encaminhamento de consultas médicas, orientação de exames de HIV, agendamentos para a advogada e a psicóloga, além de atuar no apoio emocional aos recém chegados e responsável pela organização do grupo "Desperta Mulher”, dedicado às mulheres soropositivas, que se reuniam semanalmente na sede para atividades como biodança, conversas, festejar aniversários e compartilhar experiências.

\footnotetext{
${ }^{7}$ Márcia, dentre a rede aqui desenhada é a interlocutora com a qual mantive um contato mais estreito ao longo de todo trabalho de campo. Ela acompanhou minhas angústias, conquistas, dúvidas no decorrer do processo da pesquisa e mesmo depois, ela liga para contar as últimas novidades de seus colegas.

${ }^{8}$ Ela é aposentada do INSS. Aposentou-se como cozinheira na última boate em que trabalhou.
} 
Conformam a rede social de Márcia: Nunes, 40 anos, Ensino Fundamental completo, branco, nascido em Porto Alegre/RS, mas que cresceu em Florianópolis e, segundo ele, sem definição religiosa; Renata, 42 anos, Ensino Fundamental completo, branca, espírita, nascida em Florianópolis, que depois migrou com a família de origem para Porto Alegre/RS, indo para Caxias do Sul/RS e retornando em sua adolescência para a cidade onde nasceu; Lúcia, 36 anos, Ensino Fundamental completo, branca, católica não praticante (em suas palavras, "só vai a enterros e velórios") e que nasceu e cresceu em Florianópolis; Silvia, 40 anos, Superior incompleto, católica não praticante, negra, que nasceu e cresceu em Caxias do Sul/RS; e, finalmente, Valmir, 55 anos, Fundamental incompleto, branco, católico não praticante, que também nasceu e cresceu em Florianópolis, mas hoje mora na cidade de Santos/SP.

Não mantive contato estreito com Nunes, que durante toda a minha pesquisa preferiu ficar distante da pesquisa. Fomos apresentados formalmente e quando nos encontrávamos, sempre na sede da $\mathrm{ONG}^{9}$, nos cumprimentávamos amigavelmente. Situação semelhante com Lúcia, embora com ela conversasse mais frequentemente, pois ela era funcionária da ONG GAPA. Apesar de não ter formalmente conversado com Lúcia e Nunes numa situação de entrevista, Márcia, durante todo o trabalho de campo, me mantinha informada de todas as mudanças de sorte na vida de ambos, o que prova os laços estreito que os uniam.

A rede social que tem Márcia como ego tem a característica de conformar-se de pessoas, cujas trajetórias sociais de prestação de serviços sexuais estão marcadas pela entrada no mundo das drogas. Sob esse retrospecto, acumulam um mesmo status, o de serem todos soropositivos, compartilhando, desta forma, uma condição outra de "outsiders" quanto à moralidade convencional. Além deste fator em comum, as mulheres pertencentes à rede social de Márcia pertencem a uma determinada geração de prostitutas, que iniciam sua trajetória social na região metropolitana em boates e casas noturnas e, depois, alteram seus itinerários em direção ao centro da cidade.

Márcia, diante dos seus colegas, é a mais antiga a atuar no GAPA e a mais experiente na profissão de prostituta (30 anos), o que lhe garante um lugar de respeito e poder, além da posição geracional que lhe atribui um lugar importante na circulação de informações sobre o comércio sexual em relação aos demais membros de sua rede social.

\footnotetext{
${ }^{9}$ Eu chegava na ONG por volta de 10 horas da manhã, era o horário que Márcia certamente estava lá. Raramente fiquei no GAPA sem a presença de Márcia.
} 
Ambas as posições sociais (ex-prostituta e voluntária de ONG) lhe dão status e prestígio e, por derivação, a qualificam como guardiã de uma memória social e coletiva da prostituição de casas noturnas em Florianópolis, lhe auferindo competência para dar entrevistas, palestras no rádio, cursos e em seminários promovidos pelo GAPA, bem como lhe autorizam o contato com as pesquisas para trabalhos acadêmicos.

Em termos das propriedades das interações entre os membros da rede de Márcia, a frequiência, a duração e o conteúdo dos laços internos têm estreita dependência com as ações do GAPA, sendo a intensidade das relações pautadas por razões tanto de ordem simbólica, quanto instrumental, e as quais vão desde a facilidade para conseguir medicamentos, preservativos, cestas básicas, serviços de advogados, psicólogos; até as razões afetivas, de solidariedade, companheirismo e ajuda mútua, como no caso de doenças advindas do uso de drogas ou não e o caso das DST's. nesta rede o contato era intenso, assim, viam-se quase todos os dias, trocando telefonemas ao longo da semana, marcando churrascos aos fins de semana, etc.

Márcia, invariavelmente, envolve-se com os problemas de seus colegas. Geralmente é a ela que eles recorrem, não apenas por ser a mais velha do grupo, mas principalmente por ser alguém confiável, fornecendo conselhos a todos sobre a profissão: como acumular dinheiro, distribuir os gastos ao longo do mês, os cuidados com a saúde, com a prática do sexo seguro:

\begin{abstract}
Márcia reclama do amigo Nunes que sempre está enrolado com dinheiro. Disse que não sabe se organizar com o que ganha, que ele, Silvia e Renata gastam tudo o que ganham no dia seguinte. Mas que ela sabe se organizar e sempre tem dinheiro para fazer suas coisas, pagar suas contas e andar de ônibus. Falou ainda que a Silvia foi na casa dela almoçar no domingo, que não tinha nem um centavo para comer. Disse que ainda vai me levar na casa dela. (Diário de campo, Junho de 2007)
\end{abstract}

Após o empréstimo (que fica, automaticamente, do conhecimento de todos), Márcia vive um dilema que passa a fazer parte dos assuntos entre o grupo: se o valor emprestado vai retornar, ou não; se o credor fez o que disse que faria com o dinheiro; se gastou tudo em drogas ${ }^{10}$. Mas, contudo, o possível "não pagamento" da dívida coloca o outro (aquele que deve) numa situação delicada na rede, pois se por acaso ele não pagar no período combinado, deixa de comparecer a ONG (local de sociabilidade) e, assim, não mais participa dos encontros e das conversas.

\footnotetext{
${ }^{10}$ O possível retorno ao uso de drogas (álcool, cocaína e / ou crack) é uma das causas de tensão nesta rede. Márcia é ex-dependente química e ex-alcoólatra, não faz mais uso (exceto maconha, que para ela é terapêutica), embora esteja sempre atenta para uma possível recaída dos seus amigos, pois, segundo ela, conhece os sinais de uma recaída.
} 
A rede de Márcia pode ser entendida nos moldes de uma malha estreita: as pessoas se conhecem, se encontram regularmente, embora estas pessoas tenham contatos para fora da rede (o que a configura como uma rede). Uma rede de contatos organizados a partir da família nuclear, como Silvia com o marido e a sogra, Renata com o filho, o marido e a mãe (ela não fala com o pai há seis anos) e Lúcia com o filho e a mãe. No caso de Nunes, Márcia conhece seus familiares (o tio, a tia e outros parentes).

Assim, esta rede social encontra-se mais marcada por uma valorização significativa dos laços de reciprocidade e de solidariedade, do que por conflitos e disputas, sendo, através deles, que ela obtém uma posição hierárquica de prestígio entre os demais.

As estratégias de Márcia na profissão são referidas como exemplares para os seus colegas, ela conseguiu se aposentar, reivindicando a condição do trabalho formal de cozinheira na última boate em que trabalhou na Palhoça, apesar de lá ter ocupado um cargo de prestígio, o de "amante do dono da boate", e de ter exercido a função de gerente do estabelecimento. Diferente dos demais colegas, Márcia se apresenta como tendo uma carreira vitoriosa, pois conseguiu que seu trabalho fosse reconhecido e que “assinassem" sua carteira de trabalho. Por isso, recebe um salário mínimo por mês, manifestando o orgulho em manter as contas em dia e de ter sempre créditos em seu celular.

A centralidade de Márcia é evidente, especialmente quando se observa ser ela a confidente de todos. Entre seus confidentes estão Renata e Silvia, as quais mantinham entre si uma relação bastante próxima, fato que não ocorria com os demais. Valmir, Nunes, Elisa e Lúcia tinham Márcia como confidente, entretanto, estes não mantinham o mesmo grau de intimidade entre si, nem com as demais colegas.

Em relação a Valmir, por exemplo, que tem uma especial atenção de Márcia, pois ela costuma "facilitar" suas consultas com a advogada do GAPA, seu contato é esporádico. Através de Valmir, Márcia conheceu o "Argentino", que algumas vezes ela chegou a acolher em sua casa. Segundo a direção dos laços de Márcia com os demais, fica evidente que o fluxo comunicacional é mais estreito entre Márcia, Sílvia e Nunes.

Conheci Sílvia durante minhas visitas ao GAPA para encontrar Márcia, quando ela ocupava, temporariamente, o seu lugar na recepção. Durante o meu trabalho de campo, Sílvia freqüentava diariamente a instituição, momentos em que conversávamos sobre sua vida e trajetória na profissão. Algumas vezes almoçávamos juntas, em outras, 
tomávamos um café na tarde. Silvia tem uma trajetória diferente dos demais de sua rede social. Estudou magistério e o cursou o científico. Fez, também, uma parte do curso de História, sendo que, durante a faculdade havia trabalhado num escritório de advocacia em Caxias do Sul/RS, certamente, mediado pela profissão de seu pai, contador bem sucedido na cidade.

Silva inicia sua carreira na prostituição depois de uma mudança de sorte em seu destino. Migrando de Caxias do Sul para Florianópolis e encontra trabalho numa pousada/restaurante em Canasvieiras, onde forneciam alojamento e salário. Terminada a temporada, ela não tinha para onde ir e veio para Alfândega, onde se juntou com as demais colegas que atuavam por ali e conhece as boates da rua Conselheiro Mafra, onde se insere no comércio sexual da cidade.

$\mathrm{Na}$ época da realização da pesquisa de campo, Silvia e Márcia formavam uma díade. Eram confidentes e muito próximas, se viam todos os dias, inclusive, durante os finais de semana, saiam juntas, faziam churrasco e, apesar dos fluxos, a orientação de poder incidia sobre o lugar de Márcia no centro de sua rede social. Foi Márcia que a ajudou em sua mudança para uma nova casa e também colaborou na solução de problemas burocráticos de documentação, para que ela visitasse seu marido na prisão (preso por assalto à mão armada e transferido para a Penitenciária, no bairro da Trindade/Florianópolis).

Apesar dos laços diretos que uniam Márcia e Silvia, algumas vezes a relação entre elas se tornava tensa, muitas vezes em razão das diferenças de estilo de vida e visões de mundo e onde o controle social da rede se apresentava em disputa.

Os desregramentos, em geral envolviam o mundo da infância, e eram uma das maiores preocupações de Márcia no controle social das formas das relações sociais que o grupo promovia em suas vidas pessoais. O retorno aos maus hábitos e costumes da profissão e a sua expansão para as relações familiares, envolvendo, principalmente as drogas, ocupava boa parte das tensões entre Márcia e seus próximos na rede social.

Márcia, impregnada pelo prestígio de ter superado os vícios e os maus costumes de sua profissão, tem por meta dignificar esse ofício, procurando resgatá-lo moralmente. Vale-se, para isso, das experiências negativas vividas no mundo das drogas e no universo da prostituição, maximizando sua gravidade no interior das suas relações mais próximas, sob o risco da personagem da "mulher perdida" despontar em cena:

Márcia conta que outro dia foi até as casinhas (da ONG GAPA) onde Sílvia está morando e que lá tá tudo perdido... É bebida, é maconha na frente das crianças, e 
que a Silvia se perdeu lá. Conta que foi lá outro dia e disse que estavam fumando na frente das crianças e por isso ela deu uma bronca e disse que chamaria a polícia se aquilo acontecesse de novo e então levou todos pro quarto e lá fumou também, mas os repreendeu por fumarem na frente das crianças que moram por ali. (Diário de campo, Julho de 2007)

É desse ângulo que se pode ver Márcia atuando a partir de um centro no interior de sua rede social. Um fenômeno decorrente de sua participação na ONG e de tudo que ela representava, na ocasião, para seus colegas de profissão. Obviamente que a proximidade das demais em relação à Márcia desencadeava frequentemente situações de tensão, sendo que, algumas vezes, surgiam relações laterais no sentido de neutralizar o controle social por ela exercido. Era o caso dos laços que uniam Márcia à Renata e esta às demais no interior da rede.

Conheci Renata ${ }^{11}$ no GAPA, onde passava suas tardes. Era tímida, aparentava uns trinta e poucos anos, (tinha 42), reservada, falava pouco, pele branca, cabelos ondulados e curtos até o ombro, 1,70m, magra, falava baixo e sempre ouvia as colegas em suas aventuras de fim de semana. Renata tem um filho de 12 anos, fruto de uma antiga relação, e reclamava constantemente da violência do marido para suas colegas, especialmente Márcia, que considera sua melhor amiga. Renata era alcoólatra e exdependente química, foi prostituta no centro de Florianópolis por quatro anos, época em que também foi moradora de rua. Através de Renata conheci lugares de prostituição que foram eliminados da paisagem urbana da cidade como o conhecido "dormitório do Gonzaga”, em cujo porão dormia e se protegia da polícia.

\footnotetext{
${ }^{11}$ Chego no horário marcado. Renata estava me esperando na recepção. A moça que a substituiria me olha e diz: "É essa?" (Kety uma negra temida por vários ali), Renata confirma, pega a chave da sala da psicóloga e então vamos. Ela está pálida e meio nervosa. A sala tem uma mesa com uma grande cadeira de um lado e duas de outro, uma poltrona imponente e uma outra mais simples. Pergunto qual ela prefere. Ela então escolhe a grande poltrona, pega um bloco de papel coloridinho com flores, faz algumas perguntas, meu nome, que curso faço e o meu telefone, caso precise falar comigo se não puder vir em alguma outra entrevista marcada. Explico o meu projeto, falo de tudo. Iniciamos a conversa, passei os dados solicitados e ela ficou aflita quando liguei o gravador, teve vários brancos ao longo da nossa conversa e percebi que fez um grande esforço para tentar contar sua história de maneira linear. Ela queria contar de sua vida no centro, dos momentos de drogas e da prostituição, quando falei que trabalhava na verdade com cidade, ela tentou, então, me contar sobre sua vida desde o início, em muitos momentos tentei ajudá-la, em outros me calei e deixei-a imersa na sua angústia aparente. No final quando desliguei o gravador, ela estava com muito frio, fazia frio neste dia. Ela então me conta que assistiu partes do filme da "Cristiane F. 13 anos drogada e prostituída" para se inspirar, que a própria Cristiane (protagonista do filme) começa a narrativa contando sobre o apartamento em que vivia com sua mãe (Diário de campo, Junho de 2007).
} 


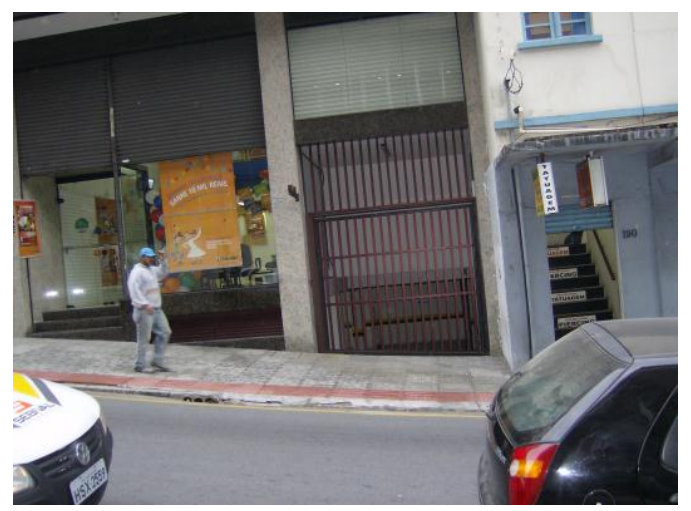

Imagem 1 - Hoje é garagem de um prédio comercial, em outros tempos o "Dormitório Gonzaga" (arquivo pessoal 2007).

Também com Renata conheci o famoso sobrado na "Conselheiro", em que ela fazia programas e que hoje tem, no seu subsolo, uma tradicional loja de conserto de sombrinhas e guarda-chuvas.

Renata conta que conseguia seus clientes na praça XV, na Conselheiro Mafra e na Felipe Schimdt. Segundo ela, na Conselheiro era mais difícil, por que tinham "as mais velhas". Então ficavam na praça XV, "que eram os lugares que mais davam dinheiro"

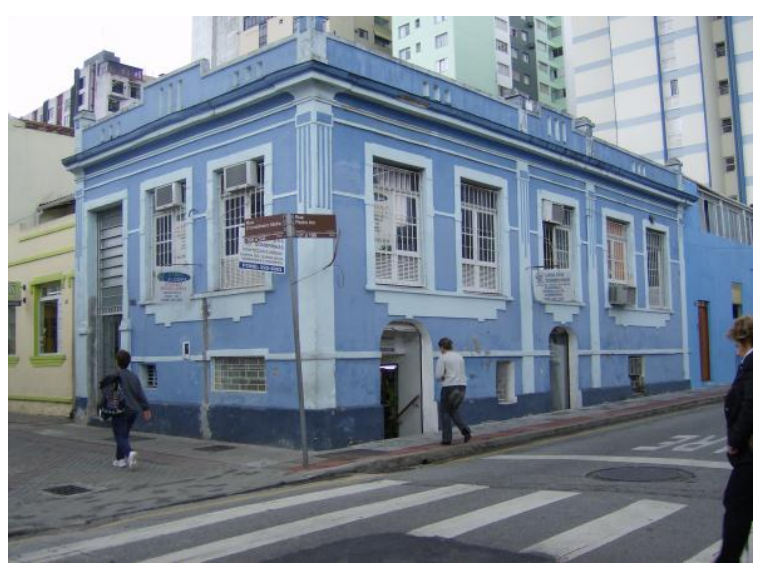

Imagem 2 - Antigo dormitório de programa Arquivo pessoal, 2007

No trajeto da rua Felipe Schimidt, Renata comenta que Márcia a convenceu a falar, disse que a faria bem, pois resgataria a Sofia ${ }^{12}$ de dentro dela. A Sofia é mais corajosa, atuante e determinada e que ela precisava da Sofia para tomar decisões de novo em sua vida. Ela então acha que se falasse na Sofia ela voltaria... (Diário de Campo, Junho de 2007).

Diferente da timidez que marca os laços de Renata com suas colegas, Elisa revela uma exuberância no trato com as colegas. Elisa tem 48 anos, é casada e cria um

\footnotetext{
${ }^{12}$ Chama de Sofia o "seu outro lado", que segundo ela: "É mais corajosa!" O nome é de uma parenta (já falecida), "antepassado dos meus avós, que vieram da Alemanha". Acha o nome forte, "preciso resgatar a Sofia de novo", ela dizia.
} 
neto de 9 anos. Seu figurino impressiona. Magra e "adorando o verão", geralmente veste saias curtas, saltos altos, blusas justas e usa unhas longas e pintadas de cores fortes (geralmente marrom escuro). Seu senso de humor, suas piadas sobre sexo e sua gargalhada são sua marca registrada. Elisa freqüenta, no interior do GAPA e à tarde (pois pela manhã tem os afazeres domésticos), o grupo "Desperta Mulher”, coordenado por Márcia:

Ficamos eu, Márcia e Sílvia depois do almoço na recepção, percebo que é local de maior descontração do GAPA... Conversam entre elas sobre uma amiga, que depois venho a conhecer, é Elisa. Elisa também é voluntária do GAPA e segundo Sílvia: "adora dar". Contam que ela estava passando mal num Posto de Saúde da Agronômica (Bairro de Florianópolis) e que ela abraçava o médico em pleno ataque epilético, "óhhh doutor João!!!" Elas davam muitas risadas, o episódio parecia ser engraçado. Esta amiga chega no momento em que estão contando o ocorrido. Ela sabe que estavam falando dela, e acha divertido quando Márcia comenta: "Tu não morre tão cedo, estávamos contando o que aconteceu contigo lá no posto da Agronômica!" Ela dá risadas e vai entrando e encontra um lugar para sentar atrás da recepção. É uma mulher magra, bonita para os seus 48 anos, usa mini-saia jeans curta, uma camisa branca cavada, (modelo física) escrito em letra prateada: PAZ, salto alto tipo plataforma, pés e mãos pintados de vermelho. Têm os cabelos curtos, uma bolsinha combinando com o resto da roupa. (Diário de campo, maio de 2007)

Em relação aos modos de conformação dos laços no interior da rede social de Márcia e suas colegas, os esforços para o resgate moral da figura da prostituta e do seu papel no mundo moderno é algo que as une. Os aspectos mais negativos da profissão, como as DST's e o uso das drogas, conformam a agenda dos encontros entre elas, orientando suas estratégias pessoais, sociais e culturais.

A agenda política dessas mulheres, devido a sua condição de soropositivas, as diferenciava de outras redes sociais no interior do GAPA, em termos das constelações de papéis normatizados (e normatizáveis) para as mulheres em carreiras de prostitutas e o mito da "mulher perdida", em oposição à figura da cortesã, único lugar de exercício da sexualidade feminina livremente exercida:

Comentei com Sílvia que ela estava muito nervosa quando falamos pelo telefone da última vez. Ela então me conta que tinha acabado de discutir com Kety. E me mostra o motivo da discussão, um jornal com uma reportagem do GAPA e uma foto em que estavam Márcia, Elisa (que conheci a tarde), Lúcia, Silvia e Dona Hilda ao centro. Conta que o mesmo editor quer fazer uma reportagem com elas sobre a comemoração do dia 05 de maio, Dia Nacional da Mulher Portadora do HIV. Ela animada, foi contar para a Kety a notícia, achando que todos iriam gostar e concordar. Ela então diz que Kety brigou: "Você só quer aparecer, é um absurdo querer aparecer no jornal, tu ainda é nova e bonita e pode arrumar um namorado se quiser..." Silvia responde: "que não estava querendo aparecer, mas queria sim mostrar para todo mundo a doença, que as pessoas não podem mais se esconder e que além do mais se ela tivesse outro namorado ele seria o primeiro a saber de sua doença!!!!” “onde já se viu????” me conta inconformada. (Diário de Campo, março, de 2007). 
Márcia, Elisa e Renata frequentemente trocam confidências, dão conselhos umas às outras, reclamam da vida. Numa das situações, observo que Elisa conta para as demais que uma vez transou com um cara, pois estava sem dinheiro e precisava comprar o material escolar do filho. Estava saindo do trabalho no shopping, quando um homem que dirigia um carro na saída do estacionamento fez um "sinal". Foram para um motel, transaram e ao final ele deu um dinheiro a ela, na negociação dos valores a serem pagos pelos serviços prestados, Elisa conta que negociou e pediu mais, podendo, assim, comprar todo material do filho, incluindo o uniforme.

Interessante observar que, no GAPA, os laços que unem Márcia à Silvia, Renata e Elisa diferenciam-se quando todas se encontram reunidas, tornando evidentes os vínculos laterais que unem Elisa à Silvia em relação aos outros menos aceitáveis no interior da rede social. As trocas sociais entre as duas últimas tende sempre a tencionar os limites da organização social entre elas, no interior dos laços que mantêm na instituição.

Nas mais variadas situações observadas durante o campo, a posição de poder e prestígio de Márcia no interior da rede social tende a dar o tom às formas de trocas sociais entre suas colegas de trabalho, mantendo as conversações entre elas sobre os detalhes do dia-a-dia na profissão, suas piadas e seus incidentes no estreito limite da distinção, do pudor e do recato exigido pelos papéis sociais que desempenham na instituição.

Elisa fala que sente dores no corpo quando não transa.... é verdade? Falo, ela: "é.... dói tudo guria......" que quê eu vou fazer dói tudo....." Continua dizendo que gosta muito de transar e que se não transa começa a sentir muitas dores. Silvia fala de uma amiga que tem problemas com lubrificação, o assunto altera-se para o tema da lubrificação. Elisa então comenta que uma amiga foi ao médico, disse que sentia dores em tudo: "Ai doutor, me dói aqui, me dói ali, na barriga, não sei o quê...." $\mathrm{O}$ médico disse: isso é pura falta de transar, é muito hormônio...." elas riem muito. Elisa reclama que o marido dela não quer transar com ela "um rapaz bonito, mas burro, só quer trabalhar!!" Márcia sabiamente acrescenta que "antigamente a mulher não podia ser lubrificada, tinha que ser seca!" (Diário de campo, Março de 2007)

Numa posição próxima a de Renata, em relação à centralidade que ocupa Márcia na rede, está a prestativa Lúcia, 36 anos, morena, magra, pela muito branca e com o rosto marcado pela acne, cabelos longos castanho-escuros sempre presos, sendo a responsável pelos serviços gerais no GAPA (serve cafezinho, sucos, faz almoço, cuida da limpeza e lava a louça).

Lúcia é ex-dependente química, foi prostituta numa boate conhecida do Estreito por cinco anos e mora na casa da mãe com o filho de oito anos. Ela tem 'problemas de 
memória’ em razão de um quadro de meningite, mas na versão de Márcia, esta condição é resultado de seu antigo passado na profissão: "de tanto pó que ela cheirou!"

Lúcia estava sempre perguntando à Márcia alguma coisa, seja porque usaram seu celular ou porque está na fissura por um cigarro, raramente mantém contato com as outras colegas (Sílvia, Renata e Elisa), a não ser quando necessário:

(....) Lúcia fica perguntando insistentemente se a Márcia queria café ou água. "Oh Márcia tu queres que eu te traga café ou água?" "Oh Márcia.... Café ou água.......". Parecia alheia a conversa das duas que tentavam se entender, ao mesmo tempo as duas (Márcia e Sílvia) também ignoravam a demanda de Lúcia. Finalmente Lúcia teve sua resposta: café. (Diário de campo, Março de 2007)

Orbitando em torno de Márcia, Lúcia está sempre trabalhando e andando de um lado para o outro, com um pano, uma vassoura e a pochete que carrega consigo e onde encontra-se um bloco, em que anota as coisas mais importantes, para não esquecer:

Lucia aparece na recepção com cara de triste e olhando desesperada para Márcia e diz: "tô na fissura...." Márcia pergunta: "De quê?" Então que Lucia responde com uma voz arrastada: "de cigarro Márcia .... aí eu não tenho dinheiro pra comprar e tô na fissura....." Silvia e Renata dizem pra comprar num quiosque que tem ao lado, ela responde que a moça não vende mais. Conta que já faz tempo que ela parou de vender cigarros: "Que aqui tem muito mala ruim!" Márcia oferece um pouco de cascas de laranja com açúcar que ela faz. Tem um pote debaixo da recepção e oferece a todas nós. Ela não aceita, diz que seu estômago "tá queimando já..." (Diário de campo, Março de 2007)

Apesar de criticá-la ("Lúcia é muito avoada, não faz o serviço direito, não limpa os banheiros!"'), a adoção de Márcia por Lúcia entre as demais colegas é evidente, quase numa espécie de missão educativa, principalmente na forma como maneja com sua família suas experiências na profissão. Na ocasião da pesquisa, Lúcia mentia para sua mãe que dormia na casa de colegas que conhecera através do GAPA, quando na verdade estava na casa de um ex-namorado, traficante, que a havia colocado na cadeia por duas vezes.

Com ares de "amor bandido", a experiência de Lúcia com o traficante desperta lembranças nas colegas, de suas antigas experiências amorosas. Entretanto, no presente, tais jogos da memória, que ela promove, acabam por criar clivagens entre ela e suas colegas, em relação aos valores e aos modos de pensar a serem adotados na profissão, em suas novas condições sociais como membros do GAPA, e que Márcia, nesse momento de sua vida, representa para todas:

Lúcia lembra que uma vez foi visitá-lo na cadeia e ao cadastrar-se para a visita íntima, outra mulher estava cadastrada para a visita como esposa. Lembrou inclusive 
do nome da mulher (ela que tem problemas com memória...). Disse que não esquece o nome completo da mulher que era a amante de seu namorado... (Diário de campo, março de 2007)

Os laços que unem Márcia e suas colegas ao mundo masculino do comércio sexual, no GAPA, se estabelecem a partir de sua condição distinta de soropositividade e seus vínculos com o submundo da droga e das boates (ou hotéis de viração). É o caso de Nunes e Valmir. Nunes é um homem de uns 40 anos, aposentado por invalidez, alto, magro, branco, olhos claros, cabelos pretos mal cortados e barba, sem dentes na frente. Usa muletas para caminhar, por conta de uma toxoplasmose contraída na infância.

Valmir, 57 anos, nascido na cidade de Florianópolis, católico praticante, neto de pescador que vendia seus peixes no Mercado Público, ele chegou a trabalhar com o avô no mercado, mas decidiu ir embora para "procurar serviço". Com mais três colegas, vai trabalhar na cidade portuária de Santos/SP: "Eu dei sorte, eu sai daqui no dia 19 de janeiro de 1966, cheguei lá dia 20 de janeiro, "Dia vinte e um já tava trabalhando na copa de um restaurante, fomos arriscar, eu tinha 16 anos..." (Extrato de entrevista, março de 2007)

Nunes nasceu em Porto Alegre/RS, mas foi em Florianópolis/SC que fez sua vida, construindo uma casa num terreno da família na Barra da Lagoa (bairro de Florianópolis), onde trabalha como artesão e pescador, e um local que Márcia vai com freqüência. Nunes conhece a rede social das prostitutas que atuam na "Conselheiro", tendo namorado com algumas delas. Como Lúcia, Nunes, é dependente químico em tratamento e conta com o apoio de Márcia em suas recaídas. É companhia frequiente de Márcia. Estão sempre juntos e dormem um na casa do outro. Se ajudam e são confidentes:

\footnotetext{
"Meteram um pedaço de pau na minha janela!!!!” Márcia não diz nada. Ele andando de um lado para outro dizendo que qualquer dia vai comprar uma arma e matar umas pessoas, "porque nesta terra só tem viado!", Márcia me olha e diz que foi o tio dele que fez isto, "só pode ser!". Ele reclama e reclama, Márcia olha pra ele e diz “calma!!! Não vai sujar tua mão de sangue, eles não valem isso!!!”, “muita calma! Deus sabe o que faz!" Fiquei impressionada como ela lembrava a Nunes ali desesperado, de Deus. Ele então, começou a reclamar de tudo. Do ônibus que deixava tudo trancado, que brigou com o cobrador falando que se pegava tuberculose nos ônibus, que as pessoas não tinham bom senso! Que todas as pessoas lhe passavam a perna, que a dentista a quem tinha pago para fazer a sua ponte, tinha fugido com seu dinheiro, ninguém prestava!!!! Falou que o programa de reabilitação da casa do GAPA não funcionava e que eles não faziam nada direito lá... Conta também que já tentou dar um curso no GAPA de artesanato, mas a presidente não deixou. Reclamou muito. (Diário de Campo, abril de 2007)
}

A intimidade de Márcia e Nunes cria, entre as demais colegas, um ponto forte de solidariedade. Os laços que uniam ambos conformavam uma relação de camaradagem, a 
partir de uma forte clivagem hierárquica entre Márcia e Nunes, onde o dinheiro, como moeda de troca entre eles, tem um valor simbólico determinante na dependência dele em relação a ela:

Márcia também conta que Nunes a chamou na semana passada para conversar. Pediu que ela cuidasse de seu dinheiro, pois vai se internar e Márcia então ficará responsável por guardar seu dinheiro. Foram até o banco e ela aprendeu tudo. Ela me contou que ele "está perdido na cachaça!” (Diário de Campo, Julho de 2007).

Em determinados momentos de meu trabalho de campo, cheguei a desconfiar que os laços que os uniam iam além da amizade e do companheirismo e, quando indagada sobre o assunto, Márcia alegava a situação de risco e insegurança em que vivia no Morro do Mocotó, por ser uma mulher vivendo sozinha, sem um companheiro, fato que a obrigava a aparecer junto a uma figura masculina, para impor respeito aos demais.

Assim, segundo ela, pedia a Nunes que cuidasse da casa e em troca lhe oferecia abrigo. Foi nessa mesma condição que seu conhecido, o "Argentino", também cuidou de sua casa. Só que, neste caso, ele “aprontou” (“Levou mulheres lá pra dentro!”), motivo pelo qual ela o cortou de sua rede social.

Em termos de laços laterais, Nunes, que era amigo de Argentino, foi o responsável por sua introdução na rede social, onde Márcia detém a centralidade dos laços. Uma figura que ocupou, por breves momentos, um lugar no GAPA ${ }^{13}$, assim como, no interior da estrutura das relações sociais que uniam Márcia e suas colegas ao outro lado do comércio sexual: o mundo masculino das drogas, dos clientes e dos amantes de prostitutas. Nessa etapa da vida de minhas parceiras de pesquisa, o empréstimo de dinheiro implicava num importante ponto de novas aprendizagens entre as profissionais do sexo, especialmente no plano dos laços de solidariedade entre elas, em oposição à antiga competição pelos clientes e o conflito pelo "ponto".

Assim, os pequenos favores, o apoio mútuo, a solidariedade e as trocas afetivas diante da precariedade das condições de vida e das dificuldades com a doença na rede social de Márcia eram um denominador importante para a manutenção dos laços entre seus/suas colegas.

\footnotetext{
${ }^{13}$ A confecção do almoço é sempre um motivo de discussões na ONG GAPA. Como a ONG vive de doações, o almoço é sempre uma dúvida e ou preocupação, basicamente todos almoçam ali e Lúcia é a responsável pela feitura da comida, como suas opções são sempre escassas e segundo os outros ali, ela não cozinha bem, o cardápio eleito por ela é macarrão com sardinha quase todos os dias o que frequentemente leva a inúmeras reclamações do cardápio repetido. Hoje, Argentino trouxe uns siris que Nunes mandou, estavam todos animados com o prato diferente. Márcia me convidou para almoçar, inclusive o Argentino tinha saído para comprar uma coca que regaria o almoço. (Diário de campo, Março de 2007)
} 
O envolvimento de Nunes com a rede social de Márcia se dá em condições próximas as de Valmir. Trabalhando na zona portuária de Santos, primeiro como cozinheiro ("como ajudante de cozinha, depois fui cozinheiro, trabalhei uns tempos na copa de restaurante né!”) e depois como garçom, torna-se amante de uma profissional do sexo e envolve-se com o mundo das drogas e dos "hotéis de viração" ("muita mulher, de todo tipo, do Brasil todo, e muita aqui de Santa Catarina. Inclusive, Santos é muito habitado por catarinense tanto homem quanto mulher. Era uma zorra total...”).

Valmir mantém laços eventuais e pouco densos com a rede social de Márcia, encontrando suas colegas quando vai ao GAPA. Márcia é a pessoa que intermedia suas relações com a advogada da instituição. Apesar dos laços esporádicos, Valmir e Márcia se vêem quando ele está em Florianópolis visitando a família. Em Santos, onde mora com os filhos, Valmir vive com uma profissional do sexo, com quem se casou depois de terminar com um casamento de dezenove anos.

Tornou-se usuário de drogas (cocaína) ao longo de sua inserção profissional como garçom nas boates. Valmir revela sua aproximação com o comércio sexual da zona portuária da cidade de Santos ao contar as intimidades da vida dos garçons com as profissionais do sexo, os cafetões, donos de hotéis de viração e de boates.

Naquela época que eu trabalhava ali, tinham.... hoje não existe mais tanto.... Tinham uns dez ou doze hotel de viração.... hotel de viração que a gente fala é hotel de puta pegar homem. Que a mulher entra com o freguês, máximo é duas horas, às vezes até menos, é só entrar fazer o programa e sair, sabe como é que é? (Extrato de entrevista, março de 2007)

Em sua inserção na rede social do comércio sexual de Santos, Valmir fala do desempenho de seu papel no interior do universo da prostituição feminina, como a figura masculina do redentor da "mulher perdida", que a retira da situação de pecado, através dos "laços matrimoniais". O "casamento" da "perdida" com o seu herói redentor lhe permite atuar na condição da figura masculina que reintegra a prostituta à sua antiga condição feminina, inscrita no modelo mítico dominante do feminino da mãe-esposa. Completa-se o ciclo, quando Valmir relata o nascimento de sua filha e onde a maternidade desponta como o último momento de recondução da figura feminina da "puta" a um todo sacralizado:

Me amasiei com uma prostituta... Inclusive ela é aqui do Rio Grande do Sul... eu tirei ela da zona, e com ela vivia maritalmente também. Ela ganhou uma filha minha, e com ela também não deu certo. Fiquei casado com essa mulher quatro anos. Aí o negócio foi pra justiça por causa da menina, eu mesmo solteiro consegui ganhar a guarda da menina... Aí eu trouxe pra minha mãe cuidar dela. Por causa dessa menina 
eu voltei pra cá e continuei tocando a minha vida. Sim, cheguei a ser dono de um restaurante, o restaurante tinha o meu nome, não deu certo, restaurante faliu... e em 1989 peguei uma toxoplasmose... (Extrato de entrevista, março de 2007)

Interessante observar que os laços que unem essa rede social são tecidos no interior das estruturas sociais estáveis que o GAPA promove entre seus membros e onde, apesar da mobilidade de seus integrantes, a coordenação de conjunto passa pela figura central de Márcia. No interior das formas dos laços que se tecem entre ela e seus/suas colegas, chamo a atenção para a sua visão singular dos riscos e dos benefícios dos papéis libertários que a figura da cortesã oferece para a condição feminina da prostituta, na forma como ela pode dispor do controle de sua libido e na expressão de sua sexualidade.

No tocante a conexidade da rede de Márcia em relação com as demais redes que seguem - Denise (Conselheiro) e Nádia (Alfândega) - penso que existem vínculos esparsos entre elas e que são pouco densos os contatos entre as profissionais.

Nos termos de Both (1976, 76), a conexidade entre elas pode "indicar a extensão" em que as pessoas conhecidas no comércio sexual local se conhecem e se encontram umas com as outras, independente do trabalho que nele executam.

Assim, esta conexidade passa por Denise (Conselheiro), Márcia conhece por conta de fazer parte do seu trajeto até a ONG GAPA. Não as conhece pessoalmente, pois a rede social de Denise pouco freqüenta o GAPA e quando vão, "é pra pegar preservativos". Além disso, o namoro de Nunes (melhor amigo de Márcia) com uma das profissionais da "Conselheiro" (já falecida) aproximou-a da rede social de prostitutas que atuam nessa parte da área da cidade.

Finalmente a rede social de Márcia passa por Nádia (da Alfândega) que a conhece da ONG GAPA, pois Nádia freqüenta, esporadicamente, o grupo "Desperta Mulher", coordenado por Márcia. Seu conhecimento se limita à família nuclear de Nádia (filhos e netos), onde mora, ou onde já morou. A recíproca de Nádia para com Márcia não é similar, Nádia sabe pouco da vida de Márcia. Sabe, basicamente, que ela foi uma "profissional", que agora trabalha no GAPA e mora no Morro do Mocotó. Não são íntimas e seus encontros são superficiais: ou na ONG GAPA ou rapidamente na Alfândega. Além da família nuclear de Nádia, Márcia desconhece sua rede na Alfândega. 


\section{As tradicionais, as divas da rua}

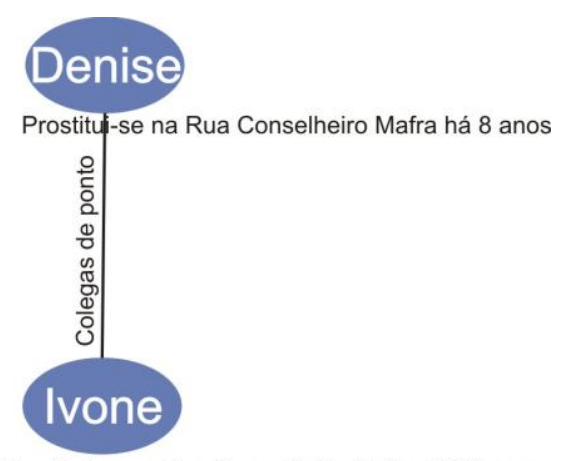

Prostitui-se na Rua Conselheiro Mafra há 20 anos

Relação próxima

Relação de colegas

Relação próxima que envolve sexo

Conhecem-se da rua e/ou por conta da atividade da prostituição

A rua Conselheiro Mafra inicia na Praça XV de Novembro, cruza todo centro da cidade, e é paralela a rua Felipe Schmidt, onde localiza-se a ONG GAPA. Ao longo de sua trajetória no centro 'a Conselheiro' (como é conhecida) possui diferentes arranjos e intensidade de pedestres, sem contar que o trânsito de veículos é interditado em quase toda a extensão da rua, permitindo o livre caminhar.

Assim, se no início ela apresenta uma paisagem urbana verticalmente intensa no que tange também a estímulos externos, além da vibrante movimentação de pedestres, ao seu final como atesta a imagem 3, ela horizontaliza-se e apresenta-se calma e silenciosa.

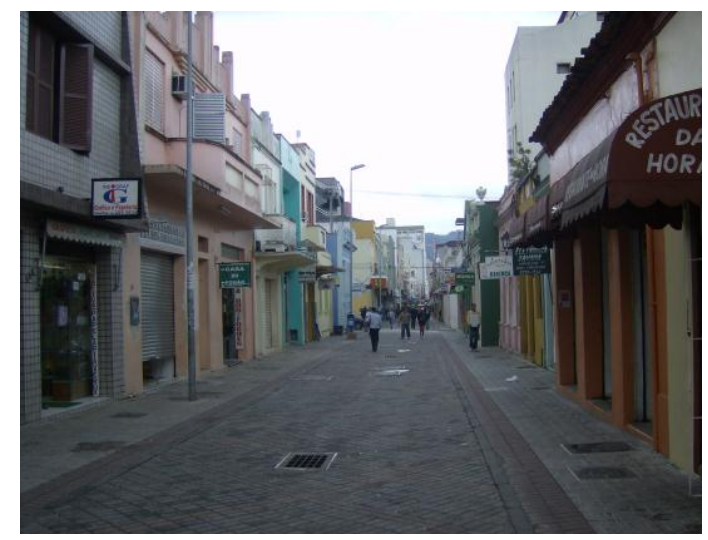

Trata-se de uma rua conforme imagem ao lado, cujo traçado é plano e composta de prédios que seguem uma mesma configuração arquitetônica, e embora reformados guardam as marcas dos sobrados construídos no final do século XIX.

Imagem 3 - rua Conselheiro Mafra (arquivo pessoal, 2007) 
É na rua Conselheiro Mafra que se situa a maior concentração de edificações tombadas do Centro Histórico de Florianópolis e, desde 2002, um dos sobrados que abriga um órgão administrativo da Prefeitura Municipal.

Como mencionado, os $\operatorname{sobrados}^{14}$ que contornam a rua (quase ao seu final) abrigam um comércio distinto em sua oferta de serviços. Lá está o 'Hospital do Fogão', que negocia toda espécie de fogão (industriais, a lenha, etc), além de peças de reposição e de trabalharem com consertos. Nesse final de rua está a molduraria mais antiga da cidade, agora com novo visual grafitado.

Também pequenos restaurantes a preços mais acessíveis do que os de outras partes do centro, distribuidoras de materiais, plásticos, revendedoras de alimentos, lojas de assistência técnica, botecos, alguns dormitórios, pequenos hotéis, sapatarias, cabeleireiros, lojas de armarinhos, móveis, equipamentos e, também, as lojas dos dois times de futebol que são rivais na cidade ${ }^{15}$.

Igualmente, é interessante destacar a localização histórica e geográfica dessa rua no contexto da cidade, uma vez que ela situa-se muito próxima ao terminal rodoviário, local de embarque e desembarque na capital. Isso faz com que esse território de passagem mantenha a função que ocupava quando a porta de entrada e saída da cidade era o cais e o trapiche ${ }^{16}$.

Esse território oferece algo que pode ser considerado como o primeiro acolhimento para aqueles que chegam à capital de ônibus. Similar a uma mancha (Magnani,2000) urbana composta de pequenos hotéis, lanchonetes, botecos, comércio de roupas, calçados, lojas de serviços e mulheres. E como num caminho pelo tempo encontramos ali ainda as antigas casas de prostituição e as whisquerias que há quase sessenta anos ocupam as mesmas esquinas no final da "Conselheiro".

Em tais territórios, encontravam-se, na ocasião do trabalho de campo, Denise e suas colegas de profissão, atuantes no comércio sexual, têm na rua o seu bureau - e, deste modo sujeitas às pressões normativas presentes em tais espaços públicos.

\footnotetext{
${ }^{14}$ Os sobrados originalmente abrigavam os proprietários dos comércios na parte superior.

${ }^{15}$ O Figueirense e o Avaí são times rivais da capital e possuem lojas que vendem artigos para os seus torcedores.

16 "É, portanto, no coração de tempos superpostos que devemos nos colocar para compreendermos o fenômeno da destruição como processo de construção perpetua do teatro da vida urbana no Brasil." (Eckert e Rocha, 2005: 25)
} 
No quadro geral das profissionais que atuam na "Conselheiro", Denise ocupa um lugar central. Ela tem 28 anos, é negra do tipo "gordinha". Nasceu em Rio do Sul/SC e chegou a Florianópolis aos 17 anos.

Denise estudou até a $5^{\mathrm{a}}$ série, e como ela mesmo faz questão de frisar, "cumpre suas obrigações na Umbanda", destacando-se por exercer o controle normativo do comércio sexual local, na distribuição regular da prestação de serviços sexuais no "ponto"

Denise configura uma díade com Ivone, 42 anos, 1,75m, magra de cabelos ondulados na altura dos ombros, estudou até a $6^{\text {a }}$ série, é católica, nascida na cidade de Santo Amaro da Imperatriz (Grande Florianópolis) e moradora da Palhoça/SC (também Grande Florianópolis).

Conheci Denise e sua colega de trabalho numa das esquinas da "Conselheiro" quase em frente a loja de fogões. Elas posicionam-se em frente a um sobrado, em que no térreo funciona um bar e no primeiro piso o Dormitório Sobrado, um "dormitório de passagem" para os encontros rápidos e fortuitos, que destoam da moralidade familiar que regula a sexualidade. Este é um dos dormitórios mais antigos da rua, próximo às boates que fizeram a fama da rua, como mostra a imagem seguinte.

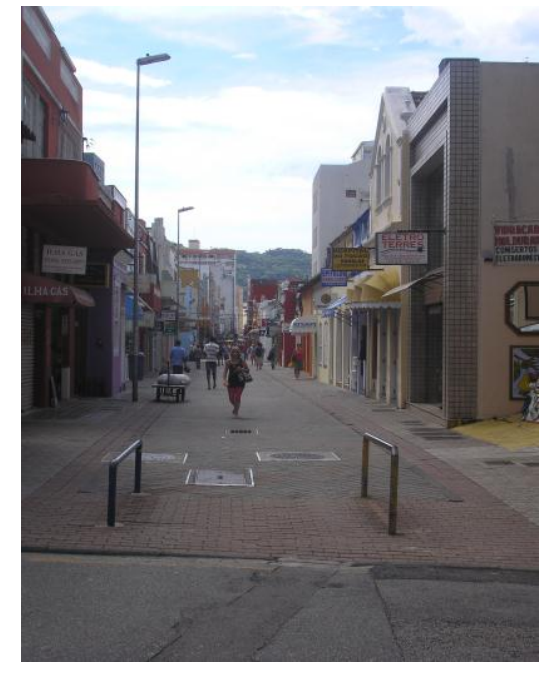

Em razão da alta temperatura e do calor do sol, as garotas ficam na sombra sentadas sobre um aramado que protege a leitura do gás. O bar está lotado, acho que é o único estabelecimento da rua em que quase não há cadeiras para sentar. Cheio de homens que discutem e conversam em voz alta. O calor impressiona e poucos são os que arriscam caminhar no sol. O barulho da rua é de vozes, da música de algumas lojas e dos carros nas transversais.

Dentro da rede social denominada por elas como "mulheres da Conselheiro", Denise e Ivone foram as parcerias mais regulares. Estavam lá, juntas, de segunda à sexta, das nove horas da manhã até a tarde (aproximadamente 15 horas), e aos sábados até ao meio-dia. O tempo de trabalho de ambas, à tarde, varia dependendo da necessidade. Para elas, o tempo de duração da "batalha" está em relação direta com a necessidade, em dinheiro, para pagar as suas contas. Quando a situação não se faz necessária, costumam largar o trabalho e ir para casa ou ao comércio. 
Em relação à propriedade dos laços que unem Denise e Ivone, é evidente o compartilhamento entre ambas de um rígido controle normativo do seu "ponto", demarcando suas fronteiras na esquina da Conselheiro Mafra com a Bento Gonçalves. A intensidade, freqüência e duração de suas atividades no "ponto" são estratégias fundamentais de sua prática de comércio sexual, definindo-se, inúmeras táticas de defesa de seu "ponto" em relação às demais colegas de trabalho e de suas respectivas redes sociais de prostituição.

No interior da rede social que tem Denise como centro (Ego), a discriminação dos papéis é evidente, aparecendo sua figura como a detentora de um saber que se traduz em poder diante das demais que eventualmente ali circulam: "Só eu fico aqui, enquanto eu tô aqui, ninguém mais pode ficar, depois que eu saio tudo bem”, diz Denise.

Da mesma forma, é na solidez dos laços de apoio e solidariedade que unem a díade Denise e Ivone diante dos riscos e perigos, que a rede social obtém as melhores condições para o exercício de seu ofício na rua, tendo em vista as exigências de grau elevado entre as parceiras de trabalho. Sem a ação de um intermediário ou patrão para organizar suas relações com os clientes, a rede social de Denise se vale, assim, de estreitos códigos de ocupação do "ponto", como garantia de estabilidade para seu trabalho.

Ao visitar a esquina da "Conselheiro" em 2002 para a pesquisa de prevenção às DST's em Florianópolis, notei que haviam, no território que hoje se organiza em torno de Denise, aproximadamente dez mulheres dispostas em pequenos agrupamentos. Apesar das normas públicas acionadas para esta parte da cidade, a maioria dessas mulheres ficava por ali conversando, fumando e bebendo, geralmente em pé, encostadas nas paredes dos sobrados, chamando a clientela para os programas. Quando o cansaço aumentava, algumas ficavam de cócoras nos cantos dos prédios. $\mathrm{Na}$ ocasião, reclamavam em uníssono do baixo movimento do comércio sexual na região e, por derivação, dos baixos rendimentos de seu trabalho.

A coesão no interior dessa rede social de profissionais, na época, representava, para alguns moradores locais, lojistas e comerciantes, um problema, pois era comum "as meninas" mexerem com os homens que por ali passavam, além do fato de que "bebiam e usavam drogas em plena luz do dia!".

Denise se estabeleceu no "ponto" sob a tutela de sua cunhada (numa clara alusão à direção dos fluxos dos papéis na família e das redes de parentesco no sistema de 
organização das relações de trabalho no comércio sexual de rua), que a conduziu, em sua carreira na profissão, ao status de "dona da quadra" com todo o seu cortejo de privilégios:

Hoje sua postura é outra, é falante, mais dona de si, desinibida, além de que fica menos tempo no ponto (em 2002 ela ficava das 8 da manhã até às 17 horas). Pergunto o que mudou desde então, comento que ela era mais tímida, ela diz que agora sou dona da quadra. É ela quem manda ali e que ninguém pode ocupá-lo ou ficar por na quadra sem antes falar com ela e sua colega Ivone: Cheguei com uma cunhada minha, mulher de um irmão meu que já é morta (de HIV) e ela me trouxe pra cá. Mas as mulheres não deixavam eu ficar. Nem era aqui na esquina. Era mais lá embaixo (da Conselheiro Mafra). Daí ela não deixavam ficar, mas como ela já era respeitada ela me botou na quadra, daí eu fiquei.... Aqui é meu ponto né... aqui não fica mais mulher nenhuma, a não ser as que já tão aqui. (Diário de campo, Julho de 2007)

Em contraste com os "tempos antigos" de sua madrinha ${ }^{17}$, Ivone e Denise obedecem a um rígido código de comportamento no "ponto", onde se destaca a prescrição no uso de roupas discretas, distante dos padrões provocantes de outras colegas suas, onde as roupas justas, os decotes, as saias curtas e a maquiagem exagerada acompanham a "caça" ao cliente.

Ao pensar na cadeia de relações de trabalho que transcorria no comércio sexual da "Conselheiro", introduzo aqui uma referência à figura da Diva. É onde a figura feminina da prostituta se destaca pelo estilo diferenciado de trabalho com seu corpo, sua sexualidade e sua libido, distanciando-se das demais formas banais de prestação de serviços sexuais.

E Denise como uma diva aconselha: não se deve "apurar na hora do programa", nem "forçar quando eles passam", pelo contrário, a profissional tem que deixar que o cliente a procure, pois "o homem que procura mulher na rua, tem que sentir que a mulher gosta dele...".

A figura da Diva alude, assim, à visão da prostituição de rua como uma espécie de arte diferenciada dos demais sistemas de práticas do comércio sexual, que têm a rua como palco. Ao afirmar seu próprio valor diante das demais, a prostituta Diva afirma seu valor diferenciado das demais colegas, tornando a arte da prostituição exercida pelas outras como uma "arte menor".

Para uma Diva não há assuntos pequenos demais, uma vez que todos eles acabam por incidir sob a forma de validação de sua arte, a da prostituição, que assim,

\footnotetext{
${ }^{17}$ Chamo de madrinha a personagem que sempre está presente nas narrativas no início das trajetórias de prostituição destas mulheres. São aquelas que as colocaram no ponto e, portanto, garantem ali sua permanência, na medida em que as apresentam às outras prostitutas, inserindo-as numa rede de suporte na rua, assim como as ensinam as artes da profissão. Geralmente são parentes, vizinhas.
} 
precisa ser feita tal qual ela a concebeu. Para ela não há uma forma certa de comércio sexual, apenas há a sua arte especial de prestação de serviços sexuais em relação às outras.

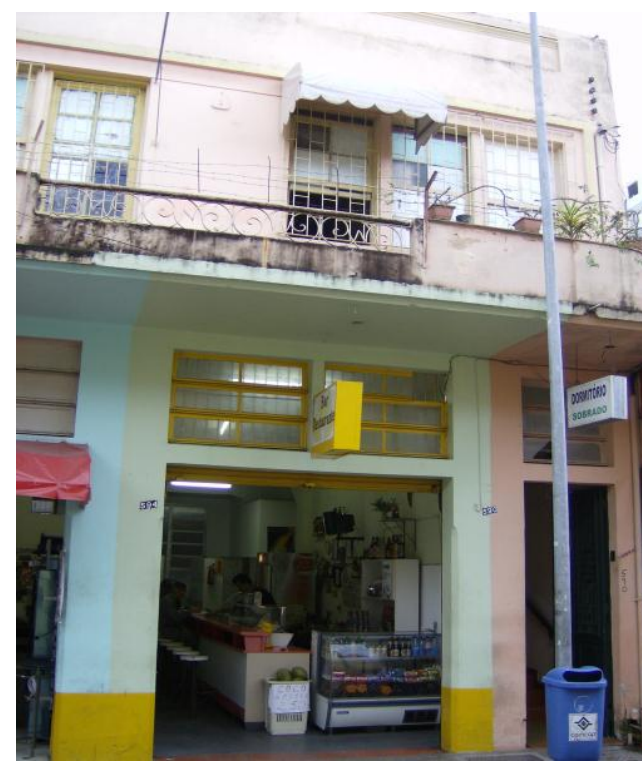

Ivone, - colega de Denise -, iniciou a carreira de prostituição na Praça XV de Novembro, ainda que Ivone seja mais velha que Denise e pertença a velha geração de profissionais que atuavam no centro da cidade, e mesmo que Ivone conquiste um lugar de destaque diante de Denise, em razão da antiguidade, é esta última quem manda ali, uma vez que, em seu ponto de vista, "Ivone é muito medrosa, mando mais que ela!". Ivone tem três filhos que moram com ela e, semelhante a Denise, todos estão cientes do seu ramo de atividade.

Em inúmeras visitas ao local de trabalho de Denise, encontrei outras colegas de trabalho, que aqui denomino de "as prostitutas ocasionais" pois, segundo Denise, "de vez em quando", prestam serviços no "ponto" e atuam no comércio sexual local para "fazer um dinheirinho", quando precisam, evidentemente, sob o aval de Denise, que dirige o setor.

Denise e Ivone batalham em regime de parceria há quase uma década no mesmo lugar - em frente ao dormitório Sobrado. Ali, elas convivem a partir de um estatuto informal (Foote-Whyte, 2005) da atividade que regula a prática da prostituição, especialmente, na confiança acordada de manter o mesmo valor pelo programa por ambas. Uma negociação que começa no valor de $\mathrm{R} \$ 30,00$.

A atuação na condição de Diva, em contraste com as mulheres da Alfândega, pode ser pensada em relação às possibilidades que ambas criam de um ganho superior 
por seus serviços a partir de um "preço mínimo". Isso implica na perícia ${ }^{18}$, por parte delas, em agregarem valor ao seu programa, além da criarem laços de fidelidade com seus clientes. Segundo o valor de mercado de sua "arte", o ganho superior ao valor ${ }^{19}$ da tabela promove certo prestígio aos serviços da prostituta na sua rede social e, portanto, no "ponto", fato que lhe garante uma margem de manobra para manter o seu preço no mercado, mas principalmente seu lugar na hierarquia:

Eu uso o meu melhor sabonete, meu melhor shampoo, meu melhor condicionador, passo meu melhor perfume, uso minha melhor roupa de baixo, estou sempre limpa e cheirosa, vou ao médico, desculpe não posso baixar meu preço! Se você quiser mais barato, vai lá na Alfândega! E continua: Estou sempre com as unhas feitas, (mostra o rosa dos pés e das mãos), então meu preço é esse! (Diário de campo, julho de 2009)

Portanto, a astúcia para implementar tais táticas diante do cliente tem por fundamento a relação de confiança mútua entre as parceiras de trabalho no interior de uma mesma rede social, as quais compartilham um mesmo "ponto".

Isto no que se refere ao sentido vertical do fluxo das relações sociais, em obediência ao controle normativo da "dona da quadra" tanto quanto lateral (horizontal) entre as colegas de trabalho. Na rede social de Denise os critérios são estreitos e rígidos, até mesmo em relação ao acesso das profissionais às bebidas e ao uso de drogas, passando pela obrigatoriedade do preservativo e considerando as regras morais típicas do calendário católico, de respeito aos dias de feriado, aos dias santos e aos sábados e domingos. Trata-se do agenciamento de ações e relações que fortalecem o "ponto" como lugar de trabalho:

Segundo Denise e sua colega de batalha, as mulheres que se prostituem em horários irregulares, nos fins de semana e a noite, o fazem porque são obrigadas por seus cafetões. Aliás para Denise ser cafetinada por um homem desqualifica uma mulher ali na rua, a coloca num lugar social de vulnerabilidade frente as colegas e a sua integridade física. Visto que elas precisam realizar mais programas, às vezes a preço mais baixo que o cobrado por suas colegas, e o pior e com qualquer um. Assim, seu preço diminui pela obrigatoriedade de levar algum dinheiro para o marido / namorado $^{20}$. Por outro lado também a expõe a riscos maiores, do que aquelas que podem escolher com quem não fazer o programa, mas especialmente, quando fazer. (Diário de campo, setembro de 2007)

\footnotetext{
${ }^{18}$ Denise fala que é sempre simpática com o cliente: "Posso estar amargurada por dentro, queimando, mas sempre os recebo com um sorriso, sou simpática, converso com eles".,.

${ }^{19}$ De acordo com Denise alguns clientes sempre dão mais (que o 'valor tabelado'), especialmente os mais antigos, isso depende do atendimento no quarto: "Tem cliente que me dá $\mathrm{R} \$ 50,00$, tem cliente que me dá $\mathrm{R} \$ 80,00$, isso varia, mas é sempre mais que $\mathrm{R} \$ 30,00$ !!”.

${ }^{20} \mathrm{Na}$ gíria da prostituição muitas vezes o namorado ou o marido são os cafetões, além de não pagar pelos programas, ela ainda lhe dá dinheiro.
} 
No consenso normativo da rede social de Denise e suas colegas de trabalho, a prostituição de rua revela-se como uma associação voluntária de mulheres trabalhadoras, referida a um sistema territorial de trabalho e segundo certas regras de organização de suas relações sociais de prestação de serviços. Diferenciam-se das demais, pois, apesar da mobilidade do trabalho na rua, acreditam que têm algo a perder se a sua "arte" se corromper no simples consumo sistemático e rotineiro de seus serviços pelos clientes. Este é o caso das mulheres que se prostituem aos fins de semana na "Conselheiro" por "não ter nada a perder".

\section{As putas ${ }^{21}$, as caçadoras da Alfândega}

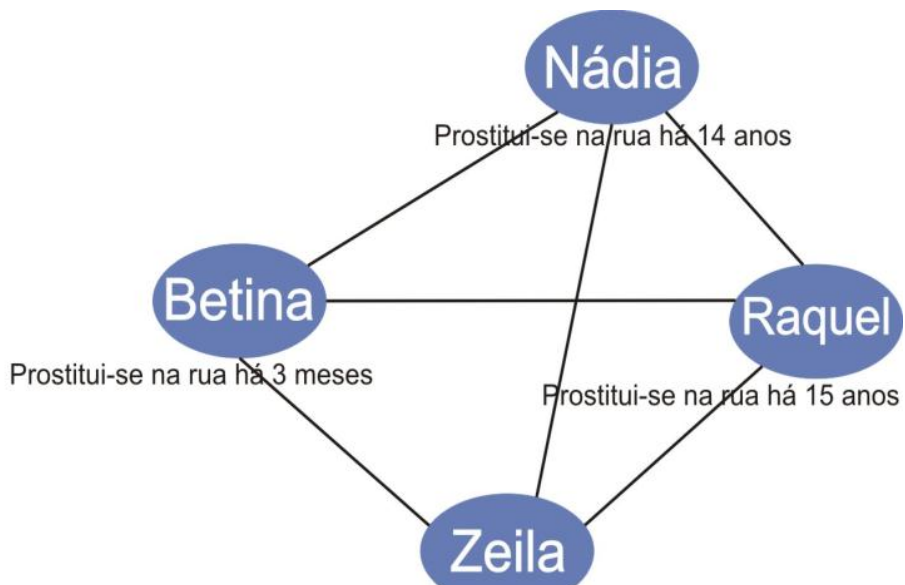

Prostitui-se eventualmente na rua há 7 anos

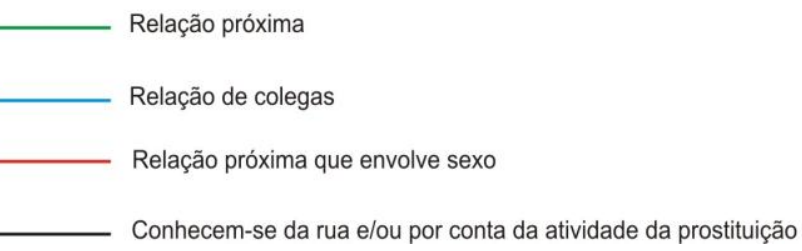

${ }^{21}$ Organizei as redes das mulheres da Alfândega e da Conselheiro ordenadas em formato horizontal e ocupando a centralidade do desenho da rede social. Material assim organizado, inicialmente por um aspecto físico / espacial, em seguida porque elas conectam-se em termos das atividades desempenhadas pelas ONG's observadas (GAPA e Estrela Guia). 
Seguindo a rua Conselheiro Mafra em direção ao centro da cidade ${ }^{22}$, o movimento de pedestres aumenta, assim como, o barulho e a verticalidade. A horizontalidade imposta pelos sobrados, na sua parte mais antiga, se desfaz e não muito longe, cruzamos com o Mercado Público e com o largo da Alfândega.

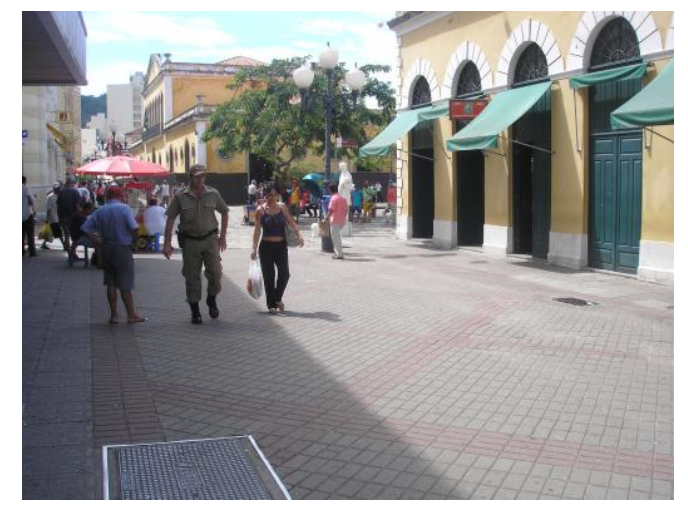

Imagem 6 - a Conselheiro Mafra esquina com largo da Alfândega (arquivo pessoal, 2009)

Foi nos limites desse agitado território da vida urbana de Florianópolis, que também pertence ao centro histórico da capital, que conheci a rede social de Nádia e de suas colegas, denominada por muitas das profissionais que atuam nas ruas como as "mulheres do largo" e ou "mulheres da alfândega".

Num primeiro olhar mais desavisado, nota-se o movimento de pessoas em torno do Mercado Público e ao lado da Alfândega. Os grupamentos formados por Nádia e suas colegas de trabalho adotam forma semelhante a qualquer outra modalidade de sociabilidade feminina convencional nas esquinas, bares e praças de uma grande cidade; não se diferenciam de outras pessoas que param por ali para descansar das andanças na cidade, sentadas nos bancos do "largo".

O número de mulheres profissionais do sexo no largo da Alfândega é expressivamente superior àquele que encontrei, durante o trabalho de campo, na "Conselheiro". Ao mesmo tempo, a população feminina é mais flutuante: em torno de 10 a 15 mulheres na baixa estação ${ }^{23}$.

\footnotetext{
${ }^{22}$ Aqui tomo como referência a praça XV de Novembro.

${ }^{23}$ Isto quer dizer entre Abril e Novembro.
} 


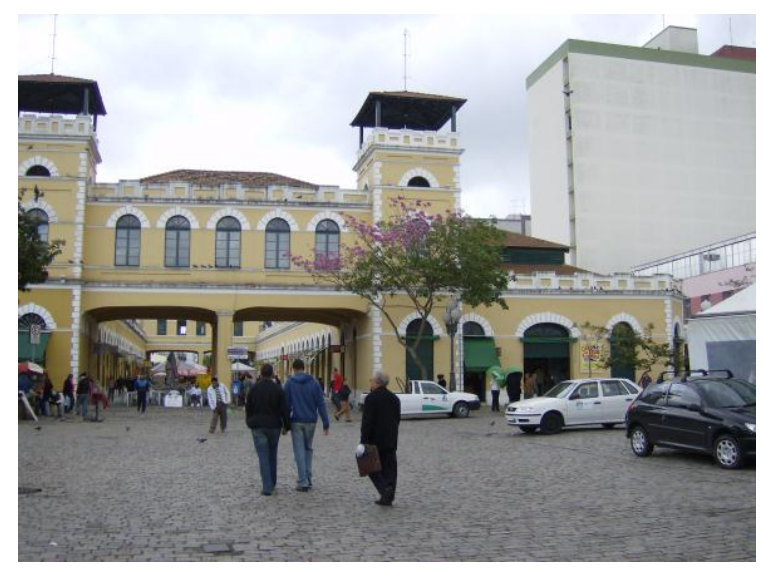

Imagem 7 - Mercado Público e largo da Alfândega (Arquivo pessoal, 2008).

Assim, geralmente, sua população tende a aumentar expressivamente durante a alta temporada (verão, férias, feriados, etc), quando o fluxo de interações sociais aumenta em razão do turismo, o que leva a pensar que o turismo sexual esta dentro da agenda de consumo cultural da cidade, como uma das atividades associadas à diversão e ao ócio (Séchet, 2007).

Aproveitando o fluxo das redes sociais que se montam e desmontam no "largo", elas permanecem sentadas nos bancos dispostos ao longo do espaço, aguardando por seus clientes fixos. As mais novas, a procura da formação de uma clientela, disputam o "ponto" com as mais antigas e mais velhas, num esforço para tornar duradoura toda uma rede de relações sociais envolvendo a prestação de serviços sexuais.

A rede social do largo da Alfândega se organiza em torno de Nádia (55 anos) e de suas colegas de trabalho. Nádia nasceu em São Miguel do Oeste/SC, filha de agricultores, veio para Florianópolis após o falecimento do pai. Estudou até a $4^{\mathrm{a}}$ série, é branca, católica não praticante, embora goste de enfatizar: "fui batizada, fiz primeira comunhão e me crismei”. Ela é viúva, mas deixou o segundo marido e trouxe consigo os filhos. No começo, trabalhou como faxineira em vários lugares da Ilha e do Continente, descreveu uma série de casas em que morou e as situações de trabalho que conviveu até que decidiu "batalhar na rua", abraçando como carreira profissional.

Atuando numa malha de relações sociais no "largo" e explorando as finalidades multidimensionais de suas interações nesse território, Nádia conhece todos os habitués da praça XV de Novembro e por todos é conhecida, do pipoqueiro ao dono do bar, do entregador de panfletos, passando pelo recepcionista do dormitório em que faz os programas e deixa suas sacolas durante o dia. 
No controle normativo do tráfico das práticas sexuais que ali transcorrem, Nádia é capaz de relatar a biografia de muitos, assim como, de suas colegas de trabalho que atuam no ponto: de onde vieram, quantos filhos tem, ou porque estão ali.

A possessão territorial de Nádia sobre o "ponto" se dá pela circulação constante, numa espécie de guarda ao seu "ponto" e de defesa de sua clientela. Depois de Raquel ${ }^{24}$ 42 anos, sua parceira de profissão, ela é uma das mais antigas no largo da Alfândega, tendo começado a trabalhar no "ponto" há mais de 15 anos. Raquel tem 42 anos, pele branca, cabelos longos e negros, sempre presos, é separada e mora com os filhos e uma neta que cria. Ela chega ao largo da Alfândega perto das 9 horas da manhã, e fica até, no máximo, às $14 \mathrm{~h}$. Trabalha apenas de segunda à sexta, com exceção das quintas, pois diz que "não rende nada!” Nos outros dias fica em casa com a família (que não sabe de suas atividades).

Ao redor de Nádia, forma-se uma rede de relações sociais estáveis, relativamente organizadas de profissionais que atuam no comércio sexual local. Entre elas, além de Raquel, Zeila, 44 anos, nasceu em São José /SC (Grande Florianópolis) e Betina, 40 anos, natural de Florianópolis, todas as três mulheres, brancas, católicas e com ensino fundamental incompleto.

Nádia destaca-se das demais por seu engajamento nas ações de prevenção das DST's da ONG Estrela Guia e, das quais participei algumas vezes, durante o trabalho de campo do doutorado junto aos dormitórios, boates e às mulheres que atuam nas ruas.

Enquanto Antônia conversa com o porteiro do dormitório, eu distribuo gel para as mulheres ali. Também ofereço pra uma senhora que carrega sacolas, a chamam de Nádia (eu já a conhecia da Alfândega), ela me parece muito gentil, tem um sorriso acolhedor, me pede preservativo feminino, vasculho a sacola e dou dois, a mulher a seu lado, que tinha acabado de fazer um programa diz que não adianta dar pra ela, que ela não sabe usar... (Diário de campo, abril de 2007)

Nádia está sempre na Alfândega, de domingo a domingo. A batalha nas ruas não prevê interrupções nos finais de semana, feriados ou dias santos, ou até mesmo no dia das mães ${ }^{25}$. Ela chega todos os dias por volta das onze da manhã (exceto aos domingos), sem hora pra voltar, apesar de morar com os filhos (Márcia diz que são os netos que ela

\footnotetext{
${ }^{24}$ Raquel foi o contato mais difícil. Ela é reservada, muito séria e a mais ocupada, deveria pegá-la entre um cliente e outro. Também a vi poucas vezes conversando com outras mulheres ali da praça, a não ser sua colega de ponto. Por intermédio da ONG Estrela Guia poderia ter tido um acesso, mas não encontram com Raquel, visto que seu horário de trabalho não coincide com as saídas de campo desta ONG, que geralmente acontecem depois das $15 \mathrm{~h}$.

${ }^{25}$ Em suas palavras, "Era dias das Mães eu fui lá, lá no Rio Vermelho na minha filha, levei dois bolos... meu filho levou de carro, ele tem carro: Vamos lá mãe, vamos lá pela Lagoa! Daí cheguei em casa tava meio garoando, era cinco horas. Oh mãe fica aí na casa, não vai pro centro hoje. Ta bom, não vou. Mas eu sabia que tinha um cliente meu que eu tinha marcado."
} 
cria). Nádia está inserida no comércio sexual em tempo integral, dispensando até mesmo a família, para dar conta de sua clientela fixa e que ela formou à muito custo no "largo": "Ah domingo, domingo eu chego só depois do meio dia .... e aí.. é todo domingo!!! Ficar em casa nada. Vim aqui pro centro e peguei cento e vinte reais.”

Nádia conta que algumas noites em que trabalha no largo da Alfândega, dorme nos dormitórios onde faz programas. Outras vezes, gosta de dançar e beber cerveja com seu namorado.

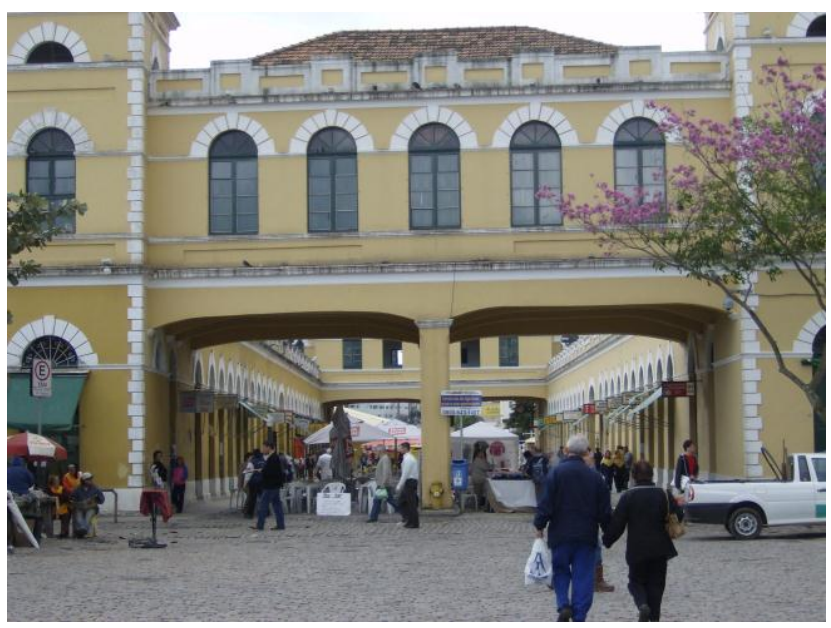

Imagem 8 - Vão do Mercado Público (Arquivo pessoal, 2008).

O "namorado" de Nádia está sempre no bar em frente ao "ponto", tomando cerveja e acompanhando o fluxo de sua clientela. Nádia comenta que ele é muito ciumento, mas na verdade a estrutura dos laços que os une tem as características daqueles que associam a puta ao seu cafetão ${ }^{26}$, pois é na condição de "namorado da puta" (Leite, 1992), que ele tem suas contas pagas por ela em troca de proteção e de certa estabilidade de vínculos afetivos e trocas sexuais entre ambos.

Contudo, o estilo de prostituição que desempenha, evidencia que Nádia é respeitada pelas demais colegas que atuam no "largo", as quais ela tem por hábito ajudar em momentos difíceis. Suas intervenções nos dramas familiares das suas parceiras de trabalho, com seus filhos, nas situações de violência doméstica, com clientes, namorados e cafetões, nas doenças e na gravidez indesejada, fazem com que Nádia ocupe uma posição de poder em sua rede social. Poder que ela costuma exercer

\footnotetext{
${ }^{26}$ Como mencionado por Denise, na hierarquia da prostituição "ter um cafetão" coloca a prostituta num lugar de baixo prestígio diante das outras colegas de métier. São mulheres que trabalham mais que as outras que não têm um cafetão. Como é preciso faturar mais, elas não têm horário regrado, se arriscam mais na rua. Isto significa fazer programas por um preço menor, em qualquer lugar, com 'qualquer um'.
} 
de forma pluralista, distribuindo seus benefícios entre as demais, ao invés de concentrálos em sua pessoa.

Ao mesmo tempo, Nádia, ao longo de sua carreira, desenvolveu um conjunto de táticas para obter benefícios em troca de sua atuação estrutural nas ONG's (especialmente do GAPA) que circulam no centro. Por conta destes contatos, tem acesso às cestas básicas, medicamentos para si e seus netos, consultas médicas, um número maior de preservativos femininos, gel, etc. Por outro lado, está amplamente inserida numa larga rede de solidariedade, unindo as profissionais do sexo na área central de Florianópolis, como na última casa em que morou, a qual foi conseguida através de contatos na ONG GAPA.

Os valores cobrados pelas profissionais do sexo que atuam no "largo" varia em função do tipo de serviço por elas prestado (boquete, punheta, sexo vaginal, etc.) e seus valores de mercado, não envolvendo, entretanto, nenhum acordo entre as redes sociais ali presentes. Mas, das "mulheres do largo", sabe-se que os serviços mais caros são os de Nadia e Raquel. Nestes, a negociação começa em vinte reais, fato que coloca sua rede social numa posição de destaque entre as demais, gerando, no fluxo de suas relações com as outras profissionais, tensões e conflitos de diversas ordens.

Raquel é muito discreta, fala baixo, é atenciosa, aparenta limpeza e cuidado, é devota de Nossa Senhora Aparecida. Não usa maquiagem, batom ou qualquer bijuteria. Sua clientela é a maior entre todas as outras prostitutas no "largo". Por isso comenta que, as "outras ali têm inveja dela porque fatura alto". Também não tolera bagunça, bebedeira ou cliente mal educado. Com Martina, sua relação é de amizade. Insistiu que Martina conversasse com a gente porque "Não tinha nada a ver responder as perguntas!".

Raquel tem clientes fixos de 15 anos e conta que o mais antigo era um viúvo, funcionário de uma empresa estatal, mas que agora casou e ela não o vê mais. Não faz mais programas fora dos dormitórios. Antes ela ia para os motéis, mas hoje tem medo, pois "nunca se sabe!".

Nos programas, ela não tira o soutien, e diz que a maioria dos seus clientes são aposentados e querem "punheta". A negociação do valor do seu programa começa em vinte reais. Muito por conta da hierarquia do largo mostrar-se difusa, assim o usuário dos serviços sente-se livre para barganhar um menor preço pelo programa, pois ele não é "tabelado", como contrariamente observado entre Denise e Ivone da "Conselheiro". 
Um fenômeno de negociação de papéis e funções sociais, reunindo as profissionais a seus clientes, de difícil compreensão, pois quando perguntava a Nadia quanto era o programa ela me dizia: “Ah, tem cliente que me dá $\mathrm{R} \$ 50,00$, outro me dá R\$ 80,00”. Mais adiante no campo, percebi que a negociação é a partir de um valor fixado.

No sentido dado por Foote-Whyte (2005) em relação a prestígio, preciso esta noção a determinadas mulheres na interação entre estas redes, algumas ali possuem maior prestígio pelas parceiras de métier, como no comentário de Nádia, quando perguntei onde estava Raquel: "Uh!!! Ela sai muito.... Tem cliente todo dia...”. Demorei a perceber quem era Raquel e também para reconhecê-la na praça.

Mais tarde, após conhecê-las, aprendi que entre Raquel e Nádia, nessa rede da Alfândega, havia uma diferença na postura do "ser prostituta". Elas batalham no mesmo espaço e possuem basicamente a mesma trajetória (ambas começaram na praça XV), mas hoje, mesmo compartilhando o mesmo lugar, estão em regiões morais distintas.

Aparentemente o trabalho das profissionais do sexo na "Alfândega" pareça se dar de forma aleatória e isolada, o estudo da rede social que tem Nadia como Ego revela bem ao contrário, com mulheres atuando em parcerias tal qual Raquel e Martina ou de Raquel e Nádia, sempre na modalidade diádica. Visto sob o ângulo exterior às redes as quais pertencem, como nos informam Nadia, Betina, Zeila ${ }^{27}$, isto é, sobre as demais "outsiders" se dissemina o valor da competição acirrada na disputa pelo cliente.

Como elas repetem frequentemente, "é cada uma por si", ficando por vezes a impressão de que é o cliente que tem o poder de barganhar o preço cobrado, dependendo dele a queda no valor dos serviços prestados. A competição do "livre mercado", segundo afirmam, é que determina o preço do serviço. Além dessa lógica de mercado, a rede das profissionais de Nádia afirma que quanto maior for a oferta de programas, menor é o valor atribuído ao serviço prestado pelas profissionais, sendo fundamental, no caso, oferecer um trabalho diferenciado das demais colegas de profisssão para "pegar" o cliente.

Descrito como uma espécie de "estado de natureza", o comércio sexual no "largo" acirraria, assim, imagem da competição entre as profissionais a partir da idéia

\footnotetext{
${ }^{27}$ Zeila tem clientes fixos, não disse com quem não fazia programas, mas criticou Betina por ter saído com um bêbado como no seguinte extrato de campo: "Zeila pergunta onde ela (Betina) está digo que ela saiu com um rapaz de braço dado, e acho que eles foram pra o Cruzeiro, fazer um programa. Ela se indigna diz que o tal rapaz estava caindo de bêbado e que vai enrolar a Betina e de novo repete "todo mundo faz ela de boba, todo mundo a enrola por ali!"”
} 
darwinista da seleção das espécies, vigorando, no fundo, a idéia, de que sobrevive o mais apto, o melhor da espécie; de que vença o melhor! Um bordão que é empregado internamente pelas profissionais que atuam nas redes sociais de prostituição do "largo" e explorado pelas demais que estão afastadas deste território de disputas. A rotatividade do comércio sexual na Alfândega é apontada, por aquelas que não atuam nesse território, como resultado de que ali "na Alfândega tem um monte de mulher, mas só mulher feia."

Entretanto, desfazendo-se mitos, no estudo da rede social de Nádia em particular, observando a rotina de Raquel, verifiquei que o contato com os clientes é sempre feito com certa antecedência, através do uso disseminado do celular entre elas. Interpelada por mim sobre como ela (Raquel) fazia os contatos com os clientes antes do celular, ou na sua ausência, ela responde: "é tudo por sinal, usa a cabeça e também não andamos juntos". Ela se refere ao fato de que, na "Alfândega" ela senta sempre com a colega, Martina, num lugar mais afastado do vão do Mercado. Quando ocupam uma das mesas de quatro pessoas, as duas sentam-se, "voltadas com o tronco para frente", conversando, mas sempre segurando o celular e a bolsa.

Martina, colega de Raquel, me diz que prefere ficar naquele espaço discretamente, porque não "era da bebida", numa clara alusão às outras "outsiders" que batalham no vão do mercado e que às vezes, costumam dançar e beber cerveja ali mesmo.

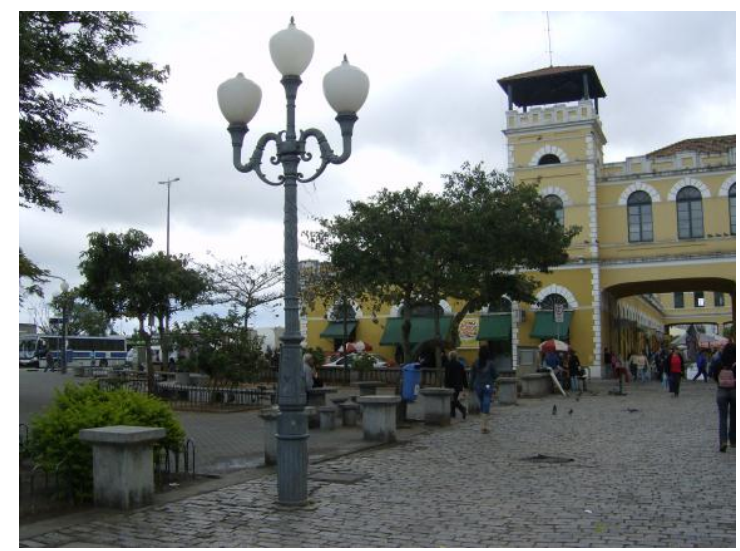

Imagem 9 - Bancos do largo da Alfândega (Arquivo pessoal, 2008)

Muito significativo é o fato que Martina ressalta, de que mantém uma relação cordial com todas ali, segundo ela "respeita todas que batalham ali", ratificando as 
propriedades normativas dos códigos ético-morais de solidariedade, instituídos por Nádia no interior de sua rede social.

No entanto, são outros os arranjos que unem, no interior da rede social de Nádia e Raquel, os laços sociais laterais entre Zeila e Betina e, também, entre Betina e Nádia.

Zeila tem 44 anos, é branca, católica, a mais bonita de todas, sempre muito arrumada, com brincos e roupas que combinam. É divorciada, mas foi casada por dezessete anos. Foi com seu ex-marido que aprendeu a administrar seu dinheiro. Mora na cidade de São José (Grande Florianópolis) e tem um filho e um neto de 8 anos, ambos morando em Blumenau/SC.

Costuma confrontar os códigos de conduta da rede social onde atua no comércio sexual. Diante das demais colegas, e o rótulo de que no "largo" "só tem mulher feia" Zeila marca presença, o que tende a intimidar as demais, em particular Betina.

Obviamente, nem Raquel nem Nádia sentem-se intimidadas pela colega, tendo em vista a própria divisão de poder que as reúne no sistema organizacional do trabalho do comércio sexual da "Alfândega".

Zeila, por seu turno, sempre aproveita a oportunidade para falar mal das "mulheres da Alfândega" que sustentam os maridos, vistos por ela como “exploradores", numa clara provocação à condição de Betina e de Nádia.

Nas disputas de poder pela centralidade, Zeila explora os seus contatos laterais, advogando que sejam elas, as profissionais, a explorar seus clientes, num claro confronto com o controle normativo pactuado no interior de sua rede social. Exemplos disso é a disputa com Nádia e Raquel, o status e prestígio obtido através da antiguidade no "ponto" e suas experiências na carreira, ao afirmar que o "velho" com quem está há mais de oito anos, já havia passado tudo para o seu nome e quando ele morrer poderá, então, usufruir de outra condição de vida.

Foi com Zeila que me atritei durante meu trabalho de campo e que denominei, jocosamente para mim, de affaire da Alfândega. Zeila constantemente me ameaçava através de recados que chegavam aos meus ouvidos de forma indireta, seguindo o fluxo democrático dos fuxicos, fofocas e mexericos das "mulheres do largo", em razão dos contatos laterais que elas mantêm entre si.

O recado era sempre o mesmo: Cuide-se "umas e outras aí querem te pegar". Circulando nas zonas mais periféricas da rede social ancorada na figura de Nádia, e na dupla formada por ela e Raquel, Zeila pouca interação mantinha com ambas, adquirindo poder nas franjas dessas redes, como no caso das neófitas, eu e Betina. 
Uma situação de hostilidade que evidenciava, entretanto, o grau de flutuação das cadeias relacionais no interior das redes sociais de prostituição denominadas de "mulheres do largo" e a formação de seus territórios sociais no comércio sexual.

Nas constelações de papéis forjados na batalha da rua, Betina e eu éramos consideradas, até certo ponto, "peixe fora d'água" por algumas "outsiders" que ali realizavam seu trabalho.

Eu, uma mulher de classe média, com curso superior, "bem de vida", gastando o meu tempo num trabalho, até certo ponto, fútil, pois o seu produto em nada mudaria a vida para elas; e Betina, "menina mimada" que por brigas infantis com a família de origem e o namorado, e alegando "não ter onde morar", decide, sem ter muitas razões, "cair na vida" e ocupar o espaço de trabalho das demais mulheres no "largo".

Betina, sem se dar conta, desafia o consenso normativo do comércio sexual e os fundamentos da profissão. Sem a solidez do apoio de uma madrinha, sem domínio algum dos repertórios de comportamento e dos papéis institucionalizados nas redes sociais, e sem contar com o auxílio da malha de relações de parentesco que apontam para o comércio sexual como uma espécie de "tradição familiar" para o gênero feminino (mãe, sogra, cunhada, irmã, etc), Betina não dispõe de experiências a serem mobilizadas para a carreira de prostituta.

Conheci Betina quase recém chegada ao "largo": pele manchada pelo sol, olhos claros, uma figura totalmente despojada diante da imponência de Zeila. Não usa batom, brincos ou qualquer adereço. Sua roupa é surrada e usava sandálias marrons empoeiradas, com meias. Ela tem mau hálito. A fala é mansa e ela é muito tímida. É separada e mãe de uma filha. Betina entra no comércio sexual após 18 anos de casamento.

$\mathrm{Na}$ batalha da rua não carrega nada consigo, tendo apenas os bolsos das calças para guardar suas coisas. Diante das colegas, Betina aparenta ser alguém que vive em condições de vida precárias (apesar de ouvir histórias que dizem o contrário). No trato com seus clientes (na época muito poucos) não costuma usar o celular. Numa situação fragilizada em relação às colegas de trabalho, Betina angariou a simpatia de Nádia que tenta desempenhar a função de madrinha, atenta aos ritos de iniciação da neófita na carreira de prostituta, Despojada de experiências sociais na aprendizagem do ofício, Nádia se esforça para ensiná-la "a combinar o serviço e cobrar antes."

Longe de Nádia, Betina costuma permanecer sozinha no "ponto" a procura de seus poucos clientes. Uma carreira difícil, de iniciação tardia, conduzida pela expressão 
usual de "não ter onde morar", resultado dos conflitos com seus pais. Betina nunca havia trabalhado na vida, sempre viveu "dentro de casa". Para ela, a prostituição de rua foi uma escolha possível numa trajetória social no interior da cidade de Florianópolis, onde nasceu e se criou. Longe da casa dos pais, casamento desfeito e com uma filha na época de meu trabalho de campo, Betina vivia um conturbado romance com seu namorado, e assim, "escapava do namorado" indo para a casa dos clientes "até se $\operatorname{arranjar}^{28 "}$

Betina, neste sentido, se afasta das experiências de vida de suas colegas de trabalho no interior da rede social de Nádia, as quais costumam ter mais liberdade e autonomia no exercício da profissão. Ainda que tenham seus namorados, gigolôs e cafetões, criando, entre eles e as "mulheres do largo", constantes áreas de atrito, a flutuação das redes, por suas formas e propriedades (em razão da densidade e intensidade rarefeita no espaço da "Alfândega"), não lhes permite um total controle da prestação de serviço das profissionais.

Assim, por sua condição social "diferenciada", Betina (a possibilidade de ter a casa paterna como uma forma de escapar da rua) não consegue angariar a cumplicidade das demais, à exceção de Nádia. Segundo Zeila, ao se valer da expressão "não ter onde morar", Betina vulgariza a condição precária de vida de suas colegas de trabalho, sendo, por isso, hostilizada pelas demais ${ }^{29}$.

Para complexificar o fluxo das relações sociais em torno de Betina, a condição de vítima que ela transpõe, para o caso de "amor bandido" entre ela e seu namorado, era fator de irritação entre suas parceiras de trabalho:

Nisso estávamos ali as três conversando passa o namorado de Betina que vem olhando pra ela.... ela fica nervosa, ele então dá um tapa na bunda dela, ela fica mais vermelha, quando ele volta, cochicha (nós ouvimos) que vai estar em casa a noite. Ela fica nervosa e ri bastante, na verdade rimos as três. As sacolas dela estavam com o cara do folheto, um senhor que entrega folheto no centro da cidade, parece que ele não dorme com nenhuma ali da Praça. Que ele gosta dela, mas ela não gosta dele e

\footnotetext{
${ }^{28}$ Betina entendia esta situação como provisória.

${ }^{29} \mathrm{O}$ "Não ter onde morar"! É outra proposição definidora que percorre toda a rede social (de Márcia, GAPA; Denise, Conselheiro e Nádia, Alfândega), o fato de ter uma casa (independente se é cedida como no caso de Silvia e - por certo período - Nádia ou mesmo alugada ou com a mãe como no caso de Lúcia) as localizam hierarquicamente numa boa posição, pois que aquelas que não têm onde morar (nem um suporte familiar) informam as suas colegas que não são competentes em organizar o dinheiro que ganham, ou mesmo pouco hábeis na manutenção de suas relações, portanto se colocam num lugar frágil na hierarquia da prostituição. Foram muitas as narrativas que demarcam o prestígio da propriedade de uma casa: "minha casa é uma casa de boneca!" ou "tenho a geladeira cheia e como do bom e do melhor!" (Zeila, Alfândega); “(...) Daí comprei uma casa lá... nunca fiquei sem casa...” (Nádia, Alfândega); “Com o dinheiro construí a minha casa, meus filhos moram comigo...." (Raquel, Alfândega); "Às vezes eu olho pra trás assim e vejo tudo que eu tenho dentro da minha casa e ah.... eu tenho bastante conforto, tenho tudo...." (Denise, Conselheiro); "Quero fazer uma casinha boa ali no Mocotó, fazer uma casinha decente, por que a minha...” (Márcia, GAPA).
} 
segundo a própria: “A gente sempre gosta de quem não gosta da gente!” Tinha dormido na casa dele e ia lá pegar as coisas. (Diário de Campo, junho de 2007)

Zeila me confidencia que as outras dali não gostam de Betina, tendo atribuído a ela o apelido de múmia ${ }^{30}$, afinal, para todas, ela tinha uma opção, tinha para onde $\mathrm{ir}^{31}$, mas o que ela queria mesmo era "ficar na rua." Ela própria havia lhe oferecido uma peça de sua casa para morar (ela construiu uma quitinete atrás de sua casa para alugar), mas Betina recusou. A adoção de Betina por Nádia era, certamente, a garantia de sua segurança entre as demais mulheres que atuavam no "largo". Nos últimos dias de campo, passando à noite pelo "ponto", encontrei Betina ${ }^{32}$ que estava feliz, pois tinha feito alguns programas e carregava para casa um pacote de pão.

\section{Algumas conclusões}

Foi no "tempo de ficar por ali" nas ruas é que observei algumas micro-regiões morais, calcificadas no espaço da praça, e que distinguiam no caso da Alfândega uma competição de Nádia versus Raquel. E num conflito silencioso de negociação da atividade, ao seguir uma espécie de "estatuto da profissão" (Mathieu, 2007), em que umas são mais profissionais que outras, que percebi que determinadas mulheres possuíam um desempenho do ofício que lhes permitia angariar certa autoridade perante as colegas. Uma autoridade a partir da antiguidade no lugar, da manutenção de uma clientela fixa, ou ainda (somando estas duas), uma discrição na prática, que resultava numa posição diferente frente às demais colegas do métier que ela reúne em torno de si.

Portanto, estas pontuações insinuam ainda que, na Alfândega encontra-se uma hierarquia mais difusa de controle do espaço, diferente do encontrado entre as mulheres da "Conselheiro", e que este controle passa pelo crivo de Nádia e de Raquel.

Também no que se refere às normas de comportamento que estruturam o fluxo das relações sociais no interior da rede, Nádia assume mais riscos do que Raquel. Ela tem um namorado/cafetão, não possui restrição de horários e é ali ,na Alfândega, que se acomoda no destino de ser prostituta.

\footnotetext{
${ }^{30}$ Múmia, porque sempre ficava em pé parada com os braços cruzados. Não conversava com ninguém, não tentava se enturmar com as outras ali

${ }^{31}$ Segundo Zeila, as outras a acusavam de ter casa e comida (a casa de seus pais com um quarto só para ela!!!), que a família tinha condições de sustentá-la, seu pai tinha uma boa profissão, era taxista no centro da cidade, e, portanto, ela não "teria motivos" para ficar ali. Também porque ela cobrava um preço muito baixo, o que era um problema para as outras.

${ }^{32}$ A última informação que tive de Betina foi por meio de Nádia (dezembro de 2009), que disse: "Betina tá batalhando lá na rodoviária".
} 
Embora, na opinião de outras redes sociais de profissionais que freqüentam o "largo", Nádia não siga a cartilha da boa prostituta, ela angaria entre as colegas um reconhecimento em razão de sua antiguidade - geracional - (também pela sua simpatia e cordialidade no trato com as demais), criando-se, assim, entre a sua rede social e as demais, um arranjo paralelo de hierarquias horizontais e verticais (Lomnitz, 2001) entre elas.

Ainda a rede social de Nádia e Raquel possui uma conexidade (Both, 1976: 76) com a rede de Denise e Ivone (Conselheiro). Nádia, Ivone e Denise se conhecem por conta do exercício da prostituição de rua, compõem-se como uma rede de malha frouxa, portanto, entrelaçadas em outras redes (de clientes conhecidos da rua). Embora ambas as redes têm, nos poucos dormitórios do centro, um denominador comum: os preços cobrados podem ser diferentes, mas os programas são realizados praticamente nos mesmos lugares. Como mencionado em Araújo (2006: 13):

\footnotetext{
"A vida de um grupo de mulheres que vivem da prostituição se interliga, de muitas formas, com a vida da cidade - ou, de modo mais, especifico, com a região da cidade em que exercem seu oficio".
}

Conforme procurei revelar ao longo deste artigo, a prostituição não abarca, assim, uma pré-disposição psicológica para a "carreira desviante" (Becker, 2008). Ao contrário, revela a relação de um dado indivíduo com esta modalidade de trabalho ao longo das experiências sucessivas no contexto das grandes metrópoles contemporâneas, fruto de sua inserção nas redes sociais de profissionais do sexo que nela existem, das interações sociais que dela decorrem e, por meio das quais, aprendem seus saberes e fazeres (De Certeau, 2000). E finalmente a rede social completa na página seguinte. 


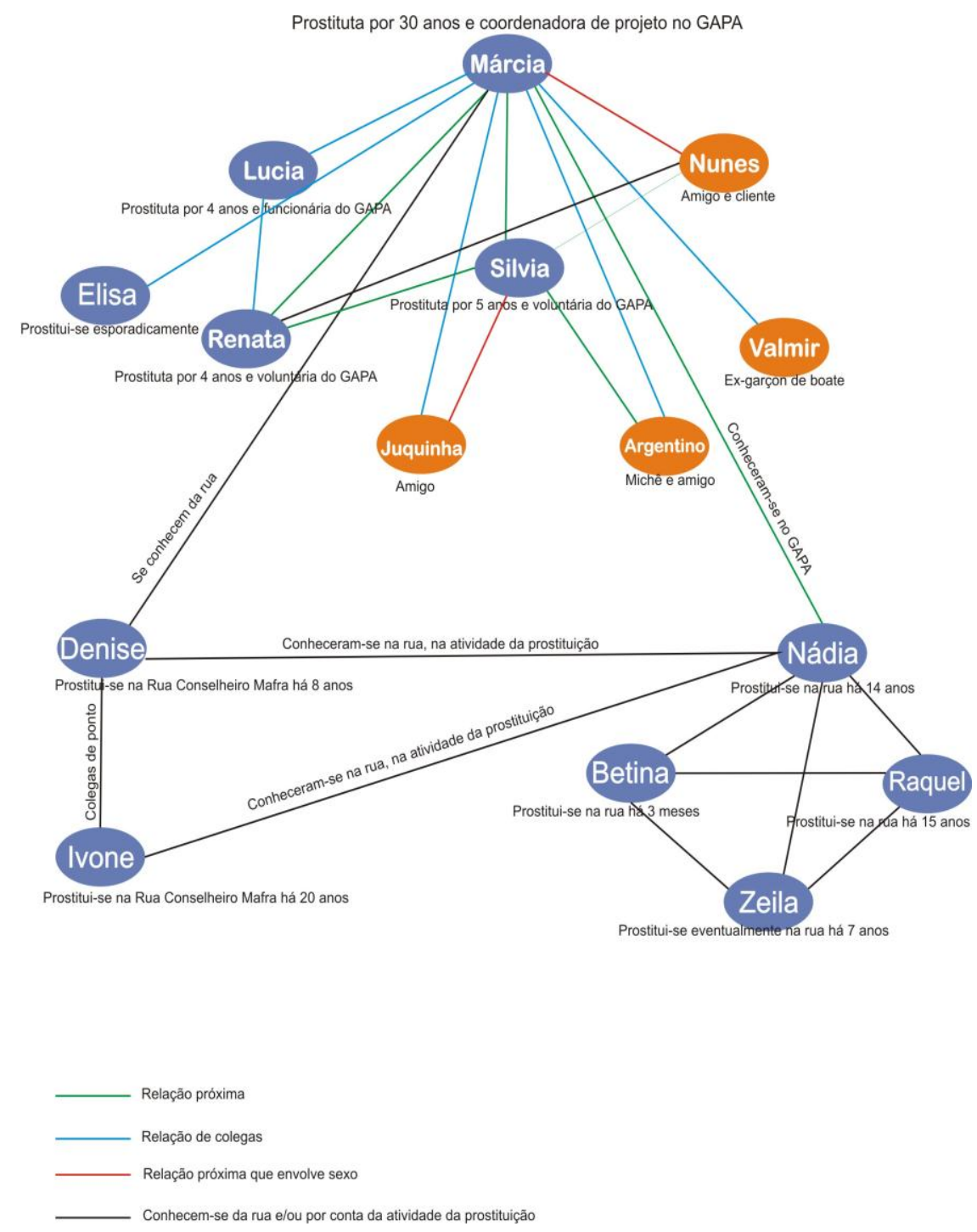

\section{Referências}

BECKER, Howard S. Uma teoria da ação social. Rio de Janeiro: Zahar editores, 1977. BOTH, Elizabeth. Família e rede social. Rio de Janeiro: Francisco Alves, 1976.

DE CERTEAU, Michel. A Invenção do cotidiano: artes de fazer. 5. ed. Petrópolis: Vozes, 2000.

DE CERTEAU, Michel. A invenção do Cotidiano: 2, morar, cozinhar. Petrópolis: Vozes, 1996.

ECKERT, Cornelia e ROCHA, Ana Luiza C. O Tempo e a Cidade. Porto Alegre: Editora da UFRGS, 2005.

ECKERT, Cornelia e ROCHA, Ana Luiza Carvalho da. "Etnografia de Rua: Estudo de Antropologia Urbana". In: RUA, Revista do Núcleo de Desenvolvimento da Criatividade da Unicamp - NUDECRI - Campinas, março 2003, número 9. p. 101 a 127. 
ECKERT, Cornelia e ROCHA, Ana Luiza Carvalho da. "Memória, Narrativa e as Histórias do Mundo". In: Revista Iluminuras, v.2, n.3. Porto Alegre: BIEV/PPGAS/UFRGS, 2001.

FOOTE WHYTE, Willian. Sociedade de Esquina. Rio de Janeiro: Jorge Zahar Editor, 2005.

HANNERZ, Ulf. Os limites de nosso auto-retrato. Antropologia urbana e globalização. In: Mana, v.5, n.1. Rio de Janeiro: FUJB/UFRJ, 1999, pp. 149-155.

HANNERZ, Ulf. Explorer la ville: élements d'Anthropologie urbaine. Paris: Minuit, 1983.

LEITE, Rogério Proença. Contra-usos da cidade: Lugares e espaço público na experiencia urbana contemporânea. Campinas: Editora da UNICAMP; Aracaju: Editora UFS, 2004.

LOMNITZ, Larissa Adler. Redes sociales, cultura y poder: ensayos de antropologia Latinoamericana. México: FLACSO, 2001.

MAGNANI, José Guilherme Cantor. Festa no Pedaço: Cultura popular e lazer na cidade. $2^{\mathrm{a}}$ edição. São Paulo: Hucitec/UNESP, 1998.

MATHIEU, Lilian. La condition prostituée. Paris: Les Éditions Textuel. Collection la Discorde, 2007.

PARK, R. A cidade: sugestões para uma investigação do comportamento humano no meio urbano. In: VELHO, O. (ORG.). O fenômeno urbano. $3^{\mathrm{a}}$ edição. Rio de Janeiro: Zahar Editores, 1976.

PEREIRA, Ivonete. As decaídas: mulheres no quotidiano de Florianópolis (1900 1940). Dissertação em História. Florianópolis: UFSC. 1996.

SÉCHET, Raymond. La fabrique de population problématique dans la ville contemporaine. Le géographes anglo-saxons face à la prostitution et au commerce du sexe. Texto apresentado no: Colloque: "La fabrique des populations problématiques par les politiques publiques". Nantes, Junho de 2007.

VELHO, Gilberto. Individualismo e Cultura: Notas para uma Antropologia da sociedade contemporânea. $5^{\text {a }}$ edição. Rio de Janeiro: Jorge Zahar Editor, 1999.

VELHO, Gilberto. A Utopia Urbana: um estudo de Antropologia Social. Rio de Janeiro: Zahar Editores, 1973.

VELHO, Gilberto. (ORG.) Desvio e Divergência: Uma Critica da Patologia Social. 8 ed., Rio de Janeiro: Jorge Zahar ed., 2003. 